NBER WORKING PAPER SERIES

\title{
BUSINESS IN THE UNITED STATES: \\ WHO OWNS IT AND HOW MUCH TAX DO THEY PAY?
}

\author{
Michael Cooper \\ John McClelland \\ James Pearce \\ Richard Prisinzano \\ Joseph Sullivan \\ Danny Yagan \\ Owen Zidar \\ Eric Zwick
}

Working Paper 21651

http://www.nber.org/papers/w21651

\author{
NATIONAL BUREAU OF ECONOMIC RESEARCH \\ 1050 Massachusetts Avenue \\ Cambridge, MA 02138 \\ October 2015
}

This work does not necessarily reflect the views of the U.S. Treasury Department or the National Bureau of Economic Research. We thank Alan Auerbach, Curtis Carlson, Martin Feldstein, Austan Goolsbee, Marty Harris, Jim Hines, Joe Koshansky, Adam Looney, James Mackie, Larry May, Janet McCubbin, Susie Nelson, Jim Poterba, Emmanuel Saez, Nina Shumofsky, Larry Summers, Alan Viard, George Yin, and Gabriel Zucman, as well as participants in the National Tax Association Spring Symposium and the Statistics of Income Consultants Panel for helpful conversations on this topic. We thank Jessica Henderson and Prab Upadrashta for excellent research assistance. Yagan gratefully acknowledges financial support from the University of California at Berkeley's Burch Center for Tax Policy and Public Finance. Zidar gratefully acknowledges support from the Kathryn and Grant Swick Faculty Research Fund and the University of Chicago Booth School of Business. Zwick gratefully acknowledges financial support from the Neubauer Family Foundation, the Polsky Center, and the Hultquist Faculty Research Endowment at the University of Chicago Booth School of Business.

NBER working papers are circulated for discussion and comment purposes. They have not been peerreviewed or been subject to the review by the NBER Board of Directors that accompanies official NBER publications.

(C) 2015 by Michael Cooper, John McClelland, James Pearce, Richard Prisinzano, Joseph Sullivan, Danny Yagan, Owen Zidar, and Eric Zwick. All rights reserved. Short sections of text, not to exceed two paragraphs, may be quoted without explicit permission provided that full credit, including $₫$ notice, is given to the source. 
Business in the United States: Who Owns it and How Much Tax Do They Pay?

Michael Cooper, John McClelland, James Pearce, Richard Prisinzano, Joseph Sullivan, Danny

Yagan, Owen Zidar, and Eric Zwick

NBER Working Paper No. 21651

October 2015

JEL No. D31,D33,E25,E62,H2,H22,H25,M2

\begin{abstract}
"Pass-through" businesses like partnerships and S-corporations now generate over half of U.S. business income and account for much of the post-1980 rise in the top-1\% income share. We use administrative tax data from 2011 to identify pass-through business owners and estimate how much tax they pay. We present three findings. (1) Relative to traditional business income, pass-through business income is substantially more concentrated among high-earners. (2) Partnership ownership is opaque: 20\% of the income goes to unclassifiable partners, and $15 \%$ of the income is earned in circularly owned partnerships. (3) The average federal income tax rate on U.S. pass- through business income is $19 \% \mid$ much lower than the average rate on traditional corporations. If pass-through activity had remained at 1980's low level, strong but straightforward assumptions imply that the 2011 average U.S. tax rate on total U.S. business income would have been $28 \%$ rather than $24 \%$, and tax revenue would have been approximately $\$ 100$ billion higher.
\end{abstract}

Michael Cooper

US Department of Treasury

Office of Tax Analysis

Washington DC 20020

michael.cooper@do.treas.gov

John McClelland

Department of the Treasury

john.mcclelland@treasury.gov

James Pearce

Department of the Treasury

james.pearce@do.treas.gov

Richard Prisinzano

Department of the Treasury

Richard.Prisinzano@do.treas.gov
Joseph Sullivan

Department of the Treasury

jsullivan@jd18.law.harvard.edu

Danny Yagan

Department of Economics

University of California, Berkeley

530 Evans Hall, \#3880

Berkeley, CA 94720

and NBER

yagan@berkeley.edu

Owen Zidar

University of Chicago

Booth School of Business

5807 South Woodlawn Avenue

Chicago, IL 60637

and NBER

owen.zidar@chicagobooth.edu

Eric Zwick

Booth School of Business

University of Chicago

5807 South Woodlawn Avenue

Chicago, IL 60637

and NBER

ezwick@chicagobooth.edu 
The structure of business activity used to be relatively simple, with C-corporationstraditional corporations subject to the corporate income tax - earning the vast majority of business income. This is no longer the case. C-corporations now account for less than half of business income, with "pass-throughs" - businesses whose annual income is taxed at the owner-level-growing rapidly in importance (Slemrod, 1996; Carroll and Joulfaian, 1997; Gordon and Slemrod, 2000; Yagan, 2015). Figure 1 shows this dramatic transformation: $54.2 \%$ of U.S. business income in 2011 was earned in the pass-through sectors, compared to only $20.7 \%$ in $1980 .^{1}$

The rise of pass-throughs accounts for much of the rise in income inequality over the last three decades. Figure 2 uses Piketty and Saez (2003) data (updated through 2013) to plot two series: the actual share of Form 1040 household income accruing to the top-1\% highestincome tax-filing over the last century and the hypothetical share holding pass-through income fixed at the 1980 level. As is well-known, the top-1\% income share doubled (from $10.0 \%$ to $20.1 \%$ ) between 1980 and 2013. Less well-known is that $41 \%$ of that increase came in the form of higher pass-through business income. ${ }^{2}$

Despite this profound change in the organization of U.S. business activity, we lack clean, clear facts about the consequences of this change for the distribution and taxation of business income. This problem is especially severe for partnerships, which constitute the largest, most opaque, and fastest growing type of pass-through. This paper uses rich administrative data to identify U.S. business owners and estimate how much tax they pay, with special emphasis on the partnership sector.

We begin by documenting who owns partnerships and S-corporations, as compared to Ccorporate and sole proprietorship ownership. Partnership ownership is particularly murky: partnerships can be owned by other partnerships which in turn can be owned by other partnerships. Partnership owners can also be foreigners, corporations, tax-exempt entities, and trusts, and partnership income and deductions need not be allocated pro rata to owners. We address these complications by systematically linking tax-year-2011 partnerships to their

\footnotetext{
${ }^{1}$ Pearce (2014) obtains a similar figure for pass-through income as a share of total business income after accounting for double-counting of partnership income paid to partnership and corporate partners, homogenizing income definitions, and including the other two major pass-through forms (regulated investment companies and real estate investment trusts) in the computation.

${ }^{2}$ Saez (2004) presents an earlier decomposition that emphasized the role of rising salary income through the 1990s which subsequently decelerated. Note that pass-through income reported on 1040 returns is pre-annual-income-taxes while C-corporate income reported on 1040 returns (i.e., dividends and capital gains) is post-annual-income-taxes (i.e., the corporate income tax). However, the 1980-2013 rise in top-1\% income shares could have been just as large if pass-through businesses had been organized as C-corporations. The reason is that owner-managers of C-corporations seeking to avoid payout taxes may report profits as managerial salary income, which escapes the corporate income tax just like pass-through profits. See Saez (2014) for evidence that top-earners' charitable contributions (a type of expenditure) have risen in lock-step with their rising income shares, consistent with a large real rise in top income shares.
} 
owners using Form 1065 K-1 information returns in U.S. tax data, following money through partnership tiers, and accounting for detailed allocations of various income and deduction streams to each owner.

We find that pass-through participation and pass-through income are especially concentrated among high-earners. Relative to households in the bottom half of the income distribution, households in the top- $1 \%$ of the income distribution are over fifty times as likely to receive positive partnership income. And the average top- $1 \%$ household earns over six-hundred times the amount of partnership income as the average household in the bottom half. Overall, $69 \%$ of pass-through income earned by individuals accrues to the top-1\%. Scorporate income is similarly concentrated, but other business income (typically considered very concentrated) is substantially less concentrated. For instance, only $45 \%$ of C-corporate income (as proxied by dividends) accrues to the top-1\%, and top- $1 \%$ households are only eight times as likely to receive C-corporate income as households in the bottom half. Furthermore, the majority of partnership income earned by the top-1\% derives from partnerships in finance and professional services. As shown below, income earned by finance partnerships is on average taxed at preferred rates.

Partnership ownership is not only concentrated, but also opaque. First, twenty percent of partnership income is earned by partners that we have not been able to classify in administrative data. ${ }^{3}$ Second, following money through partnership structures - between the partnership generating the income and the ultimate owners taxed on that income - proves challenging as well. We develop an algorithm that recursively traces income through partnership structures to ultimate non-partnership owners and attempts to assign that income back to an originating partnership. This recursive algorithm reaches a fixed point before all partnership income has been successfully assigned: fifteen percent of income is in circular structures and cannot be uniquely linked to an originating partnership. Together, the union of income flowing (1) to unclassifiable partners and (2) through circular partnerships amounts to $\$ 200$ billion or thirty percent of income earned in the partnership sector overall. ${ }^{4}$

In the second part of the paper, we estimate the overall average tax rate on business income. We define the average tax rate in a sector as the difference between the actual U.S. tax bill and a hypothetical U.S. tax bill that would prevail if all sector income were set to zero - divided by total sector U.S. income. For our baseline measure, we follow the definition of U.S. business income used for corporate taxation, so it excludes interest payments and unrepatriated foreign income. For the partnership sector as an example, this rate answers

\footnotetext{
${ }^{3}$ Unclassifiable partners are those for which processed information returns do not report the type of entity associated with a particular taxpayer identification number.

${ }^{4}$ We use the available information to approximate taxes paid on this income. Section 3.1.1 describes how we treat unclassifiable income and appendix A describes how we treat circular partnerships.
} 
the simple question: holding all other income in the economy constant, how many extra dollars of tax are owed per dollar of partnership income?

We estimate that the average income tax rate on income earned in the partnership sector in 2011 was $15.9 \%$. Extending our tax rate definition to other sectors, we estimate the average tax rate in 2011 in the C-corporate sector to have been 31.6\%, in the S-corporate sector to have been $24.9 \%$, and in the sole proprietorship sector to have been $13.6 \%$. Hence, partnership income is taxed at the lowest income tax rate in the major formal business sectors (i.e., non-sole-proprietorships). Weighted by 2011 sector income shares, these estimates imply an average tax rate on U.S. business income of $24.3 \%$. We believe this estimate to be the most comprehensive estimate available of the average tax rate on U.S. business income.

Why are partnerships taxed at a relatively low rate, even though they are owned mainly by high-income Americans who face high statutory ordinary income tax rates? Three mechanisms push the average partnership rate below owners' statutory ordinary income tax rates. First, capital gains and dividend income, which are taxed at preferred rates, amount to $45 \%$ of partnership income. This fact is especially clear in our partnership tax rate estimates by industry, with finance and real estate subject to an average rate of only $14.7 \%$. Second, tax exempt and foreign entities earn roughly fifteen percent of partnership income and pay tax rates below 5\%. Third, unidentifiable entities and circular partnerships pay an estimated tax rate $(10.6 \%)$ that is one-third lower than the average tax rate on partnership income overall. The relative flexibility in the allocation of income and deductions among partners can also combine to make the average tax burden on partnerships relatively low.

These tax rates reflect taxes paid to the U.S. Treasury on U.S. business income accruing to equity owners. To estimate an all-in tax rate on U.S. business income, we combine the above figures with total foreign tax credits and estimates of total taxes paid on business interest payments. These additional considerations give rise to an all-in tax rate on U.S. business income of $23 \%$.

In the final part of the paper, we conduct a counterfactual exercise that asks: how much higher might the average tax rate on U.S. business income in 2011 have been were it earned in the traditional C-corporation and sole proprietorship sectors, as in 1980? Specifically and for each pass-through sector, we reallocate 2011 pass-through income and deductions pro rata to the C-corporate and sole proprietorship sectors in order to match the 1980 distribution of sector income shares. We estimate that if 2011 business income had instead been earned along 1980 sector income shares, the average tax rate on U.S. business income would have been $28.0 \%$. Total business income in 2011 was $\$ 2.6$ trillion in income, so an additional 3.8 percentage points would have generated an additional $\$ 100$ billion in tax revenue.

This work connects to a long literature on U.S. business taxation and economic activity. 
First, Auerbach (1983), Auerbach and Poterba (1987), and Altshuler et al. (2009) describe trends in business tax revenue and explore the relative importance of policy and corporate profits (Feldstein and Summers, 1977) in explaining these trends. We quantify the role of the rise of pass-throughs in explaining this decline, under strong but straightforward assumptions.

Second and going back to Harberger (1962), economists have emphasized implications of heterogeneous business tax rates across sectors (Gordon, Hines and Summers, 1987). We estimate large differences in average tax rates across sectors, implying potentially large inefficiency in the U.S. business tax code under the standard assumptions of Gravelle and Kotlikoff (1989). However, recent evidence from Zwick and Mahon (2014) suggests that investment at small firms is much more responsive to taxes than investment at large firms, suggesting some efficiency gain from tilting the business tax burden toward larger firms which are mostly C-corporations.

Third, recent evidence indicates that business owners bear a substantial share of burden of business taxation, rather than it being passed on to workers or other capital owners (Suárez-Serrato and Zidar, 2014). We show that pass-through business income accrues much more disproportionately to high-earners than C-corporate income, suggesting that the rise of pass-throughs has significantly lowered the business tax burden for high-earners.

Finally, hundreds of economic models require an assumption on the U.S. federal tax rate paid on U.S. business income. Authors frequently use top statutory rates on C-corporate income: $35 \%$ (considering only annual corporate taxes) or 45\% (considering dividend and capital gains taxation as well). We estimate that this substantially overstates the average tax rate paid on U.S. business income.

The remainder of this paper is organized as follows. Section 1 details how we match business income to ultimate taxable owners. Section 2 presents descriptive statistics on who owns pass-throughs, benchmarked to owners of other business sectors. Section 3 introduces our average tax rate concept and how we apply it to the matched business-owner data. Section 4 presents estimates of the average tax rates on business income and conducts the counterfactual exercise. Section 5 concludes.

\section{Data on Businesses and Their Owners}

In this section, we detail our data sources. For the analysis of partnerships, we construct matched firm-owner data, which is crucial for computing industry-level partnership statistics. For the analysis of S-corporations, we use owner-level data. For the analysis of sole proprietorships, we use data that is by default matched firm-owner data. C-corporations 
and their owners cannot be comprehensively matched; instead, we use data from annual C-corporate income tax forms for analyses of the average tax rate and data on household dividend income as an imperfect proxy for analyses of C-corporate ownership (see caveats below).

\subsection{Matched Partnership-Partner Data}

Partnerships are flow-through entities that pay no entity-level tax; instead, partnership income is taxed at the partner-level. Our analysis of partnership tax rates therefore requires matched partnership-partner data. We first describe data sources used by previous analyses of partnership activity, income, and taxes. We then detail our algorithm for matching partnerships and partners and constructing our analysis sample covering year 2011, paying particular attention to partnership tiers (partnerships owned by other partnerships). We then assess the success of our match algorithm.

Most earlier work on partnerships has used one of two data sources. A first set of papers relies on partnership-level information derived from the Internal Revenue Service (IRS) Statistics of Income division's (SOI) Partnership Study file. Every year, SOI randomly samples partnership income tax returns (Form 1065), edits numerous variables for accuracy and consistency, and uses them to publish aggregate statistics. These annual samples contain no information on the entity's partners and the taxes those partners may pay. Earlier authors with access to tax data have used the Partnership Study microdata to analyze partnership activities and organization (e.g., DeBacker and Prisinzano (2015)). A second set of papers relies on a subset of partners, individuals who report partnership income on Form 1040 Schedule E, derived from SOI's Individual and Sole Proprietorship file. Notably, Knittel and Nelson (2011) link individual partners to their partnerships. We extend this work using comprehensive data on on all partnerships and all partners.

We link partnerships to partners by merging partnership-level Form 1065 returns (hereafter referred to as "1065s") to partner-level Form 1065 Schedule K-1 returns (hereafter "K-1s") by the unique identifier called the Document Locator Number (DLN). When a partnership files its return of partnership income on Form 1065, it is mandated to include in the same aggregate filing exactly one Form 1065 Schedule K-1 for each of its partners. Similar to other information returns filed with the IRS by an entity on behalf of a taxpayer (e.g., an individual's Form W-2 filed by her employer), each partner's K-1 details the amount of the partnership's income, deductions, and credits that the partnership is allocating to the partner. Every dollar of a partnership's income and deductions is required by law to be allocated to exactly one partner; hence, the sum of each category across a partnership's K-1s 
is mandated to match the corresponding aggregate category listed on the Form 1065.

When a partnership's aggregate filing is received by the IRS, the IRS assigns it a unique DLN. Subsequent IRS data processing divides 1065 fields into one database and K-1 fields into another database, but all retain the same unique DLN. We access unedited data for 2011 for 25,466,066 K-1s and 3,620,924 1065s in the U.S. Treasury's population tax files, which represent the near-universe of these returns. We merge these 1065s and K-1s by merging on DLN and remove K-1s without DLNs and outlier K-1s with amounts exceeding $\$ 1$ billion in any K-1 field, yielding our partnership analysis sample. Using population-level files allows us to analyze the distribution of partnership income across fine income bins and to comprehensively trace partnership income across partnership ownership tiers.

Partnerships can be owned by individuals, other partnerships, and other types of entities. But partnership income and deductions can never remain in the partnership sector: since partnerships cannot retain income, every dollar must eventually be distributed to nonpartnership "ultimate" owners. Where possible, we follow income flows through ownership tiers to ultimate owners along the lines of earlier methods (May, 2012). This exercise allows us to make statements about the tax rate for particular solved partnerships or for specific industries within the partnership sector. We refer to partnerships or groups of partnerships in which all income can be traced to ultimate owners as "solved" partnerships. However, there are some circular ownership chains, and they are quantitatively important: $14.9 \%$ of income flowing to ultimate owners is associated with circular partnerships. We further describe these circular partnerships in section 4, which presents our tax rate estimates, and in appendix A, which provides more detail on our aggregation algorithm.

Finally, we match individual partners to the universe of unedited 2011 Form 1040 returns by linking partners' masked social security numbers to the masked social security number of either the primary 1040 filer or the secondary 1040 filer. For the analysis of ownership across the household income distribution in section 2.2, we top code individual K-1 records when the absolute value of total partnership income exceeds 100 times the absolute value of adjusted gross income (AGI) as a simple ad hoc way to account for likely erroneous or unrepresentative outliers. For these records, we set partnership income equal to $100 \times$ $\operatorname{sign}($ partnership income $) \times|A G I|$.

We successfully match $97.7 \%$ of 1065 s to at least one K-1 by DLN. We believe that match rates are below $100 \%$ because of some combination of DLN manual entry error, taxpayer non-compliance (the partnership failing to issue $\mathrm{K}-1 \mathrm{~s}$ ), and potential isolated errors in data processing. Many partnerships' K-1 income fields do not sum to the partnership's total for those income fields as reported on the partnership's tax return. However in aggregate, the matched K-1s allocate to partners the vast majority of partnership income. For example, 
the sum of ordinary business income across the K-1s equals $98.2 \%$ of aggregate ordinary business income of the 1065s as computed from the 2011 SOI Partnership Study File; for long-term capital gains, the figure is $98.7 \%$.

We use the following variables, organized here by form.

Form 1065. Industry equals the principal business activity (NAICS) code reported in Box A.

Form 1065 Schedule K-1. Total partnership income equals the sum of the K-1 fields available to us from the unedited K-1 population data, across each partnership's partners' K-1s: ordinary business income, net rental real estate income, other net rental income, guaranteed payments, interest income, ordinary dividends, royalties, net short-term capital gain, and net long-term capital gain, less Section 179 expenses. We lack all other fields, most notably other deductions and foreign tax credits.

Form 1040. The adjusted gross income (AGI) equals the adjusted gross income on the individual partner's Form 1040 filing; it equals zero for non-filing individual partners.

Various business income forms. Partner type equals "Individual" if the K-1 indicates that the partner is an individual. If not, partner type equals the type of business income tax return to which we match the partner's masked taxpayer identificaton number (TIN). ${ }^{5}$ Partner type equals "Unidentified TIN type" if the partner is neither an individual nor was matched to a business income tax return; it equals "Unidentified EIN" if the IRS database classifies the taxpayer identifier as an employer identification number (EIN) but we are unable to match this EIN to a business income tax return. When we refer to partner types below, we use these groupings:

\begin{tabular}{ll}
\hline Partner Type & Form Filed \\
\hline Individual & 1040 \\
C- and other corporations & $1120,1120 j \forall j \in\{\mathrm{F}, \mathrm{PC}, \mathrm{L}, \mathrm{RIC}, \mathrm{REIT}, \mathrm{H}, \mathrm{C}, \mathrm{POL}, \mathrm{ND}, \mathrm{SF}, \mathrm{FSC}\}$ \\
S-corporations & $1120 \mathrm{~S}$ \\
Tax-exempt & $990,990 j \forall j \in\{\mathrm{T}, \mathrm{R}, \mathrm{PF}, \mathrm{ZR}, \mathrm{C}\}$ \\
Estate/trust & 1041 \\
Foreign person/entity & $1042,1042 \mathrm{~S}, 8805,8288 \mathrm{~A}$ \\
Partnerships & $1065,1065 \mathrm{~B}, 1066$ \\
Unidentified EIN & Taxpayer identifier classifiable as EIN, but tax form unknown \\
Unidentified TIN type & Taxpayer identifier not classifiable \\
\hline
\end{tabular}

\footnotetext{
${ }^{5}$ We match non-individual partners to the universe of twenty types of business income tax returns from complete years available in Treasury's population business income tax return files (1996-2013). In the few cases when a single partner matches to multiple business return types, we break such ties by proximity of the matched business income tax return to 2011.
} 


\subsection{Matched S-corporation-owner Data}

Our approach to matching S-corporations to owners is similar to the one followed above for matching partnerships to partners. Like partnerships, S-corporations are flow-through entities that generally pay no entity-level tax; instead, S-corporation income is taxed at the owner-level. However unlike partnerships, S-corporations are owned only by individuals, so there is no issue of ownership tiers or other complicated structures, which simplifies the analysis. Therefore we use the data on the near-universe of 2011 Form 1120S Schedule K-1s (analogous to the Form 1065 Schedule K-1s with similar fields available as detailed above) from Treasury's population tax files and match to the owner's Form 1040. ${ }^{6}$

\subsection{Sole Proprietorship Data}

Sole proprietorships are unincorporated business entities owned by individual taxpapers, and their income is reported on Form 1040 Schedule C. Thus the distinction between entity-level and owner-level taxation is moot for sole proprietorships, and sole proprietorships are by default linked to their owners on 1040's. For the analysis of sole proprietorship tax rates, we use the SOI Individual and Sole Proprietorship sample file (see section 1.1 for a description of SOI study files). For the analysis of the distribution of business ownership and income, we use information on the near-universe of 2011 1040's in Treasury's population tax files.

\subsection{C-corporation Data}

C-corporation income is taxed at both the entity level and at the owner level: annual income is taxable at the entity level, and net-of-annual-income-tax earnings are taxable at the owner level when distributed as a dividend or realized as a capital gain. For the analysis of Ccorporation tax rates, we proceed in two steps. First, we use the near-universe of 2011 Form 1120 returns from Treasury's population tax files to estimate tax rates on annual C-corporate income. We then use estimates from the literature as assumed tax rates on C-corporate distributions. For the analysis of the distribution of business ownership by and income to individuals, we use (as an imperfect proxy for C-corporate ownership) dividend income as reported on the near-universe of Form 1040's in Treasury's population tax files. ${ }^{7}$

\footnotetext{
${ }^{6}$ Prior work matching S-corporations to their owners includes Bull, Fisher and Nelson (2009) which linked the SOI 2005 sample of S-corporations to their owners via K-1s.

${ }^{7}$ This is an imperfect proxy for C-corporate ownership and income by individual tax-filing units because some C-corporation income is distributed to shareholders as capital gains, because many C-corporations do not distribute income at all in a given tax year, and because some non-C-corporation income is included in the dividends Form 1040 field. We do not analyze capital gains because many capital gains do not derive from C-corporation ownership; dividend income and capital gains exhibit similar ownership patterns. We
} 


\section{Who Owns Businesses in the Pass-through Sector?}

We now use the data detailed in the previous section to describe pass-through (partnership and S-corporation) owners. We first focus on partnerships, documenting the share of partnership owners ("partners") that are individuals, C-corporations, S-corporations, and other partners and also the share of partnership income allocated to these partner types. We then document the distribution of partnership, S-corporation, sole proprietorship, and C-corporation income earned across the individual income distribution.

\subsection{Partner and Income Shares Across Types and Industries}

Figure 3 divides the 25.3 million partner $\mathrm{K}-1 \mathrm{~s}$ in the distribution analysis sample into one of seven partner types: individuals, C- and other corporations, S-corporations, estates and trusts, tax-exempt organizations, foreign entities, partnerships, and those partners whose type could not be identified. A large majority of partners (73.9\%) are individuals. The second largest identifiable category is partnerships (5.6\%). Another $5.0 \%$ are estates or trusts. Another $2.9 \%$ are corporations, with slightly more S-corporate partners than Ccorporate partners. The remainder is divided among the other partner types.

Note that even with administrative data, it is not possible to identify all of the partners. For $9.5 \%$ of partners, we are not able to find a tax return associated with the partner's taxpayer identification number. For the majority of these unidentified partners, we cannot assign an entity type; however, we suspect that most of this income is paid to corporations (see section 3 below for more detail).

Figure 3 displays a substantially different division of partnership income across partner types. Though individual partners constitute $73.9 \%$ of partners, they receive only $31.5 \%$ of partnership income. Corporate partners on the other hand are allocated a much larger share of partnership income (7.7\% for C- and other corporations and 3.4\% for S corporations) than the share of partners that they constitute $(2.9 \%)$.

Three additional points are worth noting. First, partnerships themselves receive $26.3 \%$ of partnership income allocations. Thus, any analysis of partnership activity must address the issue of ownership tiers. Second, a disproportionate share of income accrues to taxexempt and lightly taxed entities (10.9\% to tax-exempt and foreign partners). Note that unlike C-corporate income, which is taxed at the entity level, partnership income earned

include both qualified and unqualified dividends. Unqualified dividends includes dividends from domestic C-corporations in certain circumstances as well as dividend income paid by foreign corporations, dividend income earned by pass-throughs, and money market interest. Note that the inclusion of money market interest likely raises participation rates and income shares outside the top of the income distribution relative to excluding it. 
by tax-exempt entities may not be taxed at all. Third, $14.8 \%$ of income (including income paid to other partnerships) accrues to entities that we cannot classify. This fact introduces a challenge for the estimation of tax rates on partnership income.

Figure 4 shows the distribution of partnership income across partnership industries. The partnership used to be a niche business form, only of use to groups of people who worked together and shared general liability. Traditional partnerships, such as law and accounting firms and doctors' offices, are still present and account for as much as $14.9 \%$ of total partnership income. ${ }^{8}$ But they are no longer representative of the median partnership in dollar-weighted terms; $70.0 \%$ of allocated income goes to partnerships in finance or those that classify themselves as holding companies. ${ }^{9}$ This is consistent with the evidence in DeBacker and Prisinzano (2015) showing that partnerships with limited liability are now the most common form of partnership, and that many entities - which may have organized as corporations in the past to enjoy limited liability protections - now choose this flexible pass-through form.

\subsection{Business Ownership across the Income Distribution}

Figure 5 displays participation rates by business income type across the income distribution of U.S. tax filers. ${ }^{10}$ To create the graph, we divide all 145 million 1040 filing units ("households") from year 2011 into percentiles of adjusted gross income (AGI, including all returns regardless of whether AGI is positive, negative, or zero). We then compute the share of tax filing units within each percentile bin that earned positive income from each of the four business sectors we analyze in this paper: sole proprietorship income (defined as positive 1040 Schedule C income), C-corporation income (defined as positive 1040 dividend income $)^{11}$, S-corporation income (defined as either the primary earner or the secondary earner having been issued a Form 1120S Schedule K-1 with positive summed income), and partnership income (defined as either the primary earner or secondary earner having been issued a Form 1065 Schedule K-1 with positive summed income). ${ }^{12}$ Note that these defini-

\footnotetext{
${ }^{8}$ These partnerships are typically organized as general partnerships, in which all partners are jointly or separately liable for the debts, taxes, or tortious liability of the partnership. This structure is not attractive for most business organizations, because the owners' personal assets are not protected (DeBacker and Prisinzano, 2015).

${ }^{9}$ This category also includes real estate and insurance industries, which together account for less than five percentage points of the total.

${ }^{10}$ We stress that these results are not based on the Treasury distribution model. We use an adjusted gross income distribution for filing units only, rather than family-size-adjusted cash income for the population.

${ }^{11}$ See footnote 7 for the caveat that "C-corporation income" here includes some income that does not derive from C-corporations and excludes non-dividend C-corporation distributions.

${ }^{12}$ We use positive income rather than all income in order to avoid negative income shares at the very bottom and because dividend income is never negative. The relative skewness of top-1\% pass-through participation
} 
tions consider only direct taxable business ownership and thus, for example, do not reflect indirect business ownership via pension funds or via tax-deferred retirement accounts.

The figure displays striking patterns of participation rates across the income distribution by business type. First, a relatively constant share of households-between $8 \%$ and $15 \%$ - participate in a sole proprietorship with relatively isolated exceptions. Second, participation rates in C-corporation income is over eight times higher at $80.4 \%$ among the top-1\% (households with over $\$ 375,738$ in AGI) than in the bottom half of the income distribution. However, many households at every AGI level own publicly traded dividend-paying stocks; as a result, participation rates in C-corporation income are substantial (no lower than 7.3\%) in every AGI bin. Third and similar to C-corporate participation, partnership participation rates are also high among top-1\% households (71.3\%). But unlike C-corporate participation, partnership participation rates are trivial among bottom-50\% households: partnership participation is over fifty-one times higher in the top- $1 \%$ than in the bottom half of the income distribution. S-corporation participation exhibits skewness similar to partnership participation. Hence, pass-through participation is very concentrated among high-income households relative to these other two traditional forms of business activity.

Figure 6A shows that pass-through income is even more concentrated among high-income households than pass-through participation and other forms of business income. To construct this figure, we use the same data underlying the previous graph and, for each type of business income, plot the share of that type of positive business income earned by households in each AGI percentile. Thus within each series, the values of the one hundred data points sum to $100 \%$. If a given type of business income were equally distributed across households, the series would be a flat line at $1 \%$. Instead, each type of business income is highly concentrated among the economy's highest-earning households. However, the degree of concentration varies by business income type. Whereas $16.2 \%$ of total sole proprietorship income is earned by the top- $1 \%, 44.7 \%$ of total C-corporation income is earned by the top-1\%. Pass-through income is even more highly concentrated, with the top- $1 \%$ earning $66.9 \%$ of total S-corporation income and $69.0 \%$ of total partnership income.

Figure 6A may make it seem that since the top-1\% earn most pass-through income, most pass-through income earned by individuals is taxed at the top ordinary income tax rate (35\% in 2011). One reason this need not be the case is that a large share of partnership income is portfolio investment income that is taxed at preferred rates. As a preview of the comprehensive analysis of the character of business income in Section 3, Figure 6B zooms in on the previous figure 6A's partnership income series in order to show the distribution of partnership income from three partnership industries: accommodation and food service and income shares hold even when using an absolute-value-income concept. 
(NAICS 72), professional services like law and accounting (NAICS 54), and finance and holding companies (NAICS 52, 55, and 531). If all industries were shown, the sum of each percentile bin's data points in this figure would equal the bin's corresponding partnership series data point in figure $6 \mathrm{~A}$.

Figure $6 \mathrm{~B}$ shows that most of the partnership income accruing to the top- $1 \%$ accrues from partnerships engaged in finance and company holding. Of the $69.0 \%$ of partnership income that accrues to top-1\% households, 36.6 of those percentage points accrue from partnerships in the finance and holding company industry and another 16.0 accrue from partnerships in the professional services industry. In contrast, only 0.6 percentage points accrue from the accommodation and food service industry, a traditional "mom-and-pop" industry. Taking into account all AGI percentiles, nearly half (48.7\%) of partnership income earned by individuals accrues from partnerships engaged in finance and company holdingmuch of which is portfolio income taxed at preferred rates. ${ }^{13}$

The following two sections take comprehensive account of different types of income streams being taxed at different rates across the individual partner, corporate partner, and other partner income distributions in order to provide estimates of tax rates paid on partnership income in the United States.

\section{Methodology for Estimating Average Tax Rates}

This section describes how we calculate average tax rates on business income from partnerships, sole proprietorships, S-corporations, and C-corporations. These tax rates are important inputs for estimating the average tax rate on business income in the United States. In addition, C-corporations themselves, for example, can be partners, so we need to be able to assign a tax rate to partnership income flowing to C-corporation partners.

\subsection{Partnership Income}

The average tax rate on partnership income depends on the tax liabilities and incomes of partners. We calculate tax rates on partnership income at three levels. First, we follow income flows to partners and assign a tax rate to each payment from a partnership. Second, we calculate tax rates at the partnership level. Third, we calculate tax rates at the level of the overall partnership sector.

\footnotetext{
${ }^{13}$ These findings are consistent with Kaplan and Rauh (2010), who show that partners at top law firms and Wall Street-related individuals - including hedge fund managers, PE, and VC professionals whose firms are usually organized as partnerships - earn a large and increasing share of the income at the top of the AGI distribution.
} 


\subsubsection{Tax Rates on Income Distributed to Partners}

We calculate tax rates for each payment that partners receive from a given partnership. For these calculations, we use U.S. Treasury's Office of Tax Analysis (OTA) tax calculators where possible and directly assign tax rates otherwise. We define a tax rate $T_{i k}$ on income type $i$ to partner $k$ from all partnerships $p$,

$$
T_{i k}= \begin{cases}T_{i k}^{\mathrm{OTA}}=\frac{T A X_{i k}}{Y_{i k}} & \text { if } k \text { files form } \in\{1040,1120,1120 \mathrm{~S}\} \\ T_{i k}^{\text {Assigned }} & \text { otherwise }\end{cases}
$$

where $Y_{i k}=\sum_{p \in \mathcal{P}} Y_{i k p}$ is the sum of payment of income type $i$ to partner $k$ from all partnerships $p$ in the set of partnerships $\mathcal{P}, i$ is an income type in the set $\mathcal{I}=$ dividends, interest, capital gains, ordinary business income $\}$, and $T A X_{i k}$ is the tax liability from the OTA tax calculator.

For partners who file a tax form for which we have a tax calculator, we recalculate each partner's income tax liability in the hypothetical case that they earned no positive (or negative) income of that income type from all partnerships. For each partner, we consider income without replacement in the following sequence. We first remove capital gains income, then dividend income, then schedule $\mathrm{E}$ income (ordinary business income), and then interest. The difference between actual tax liabilities and hypothetical tax liabilities is the numerator of our average tax rate measure. For example, in the case of capital gains income, the numerator of our average tax rate measure is:

$$
\begin{aligned}
T A X_{i k} \equiv & \text { Tax Liability }_{k} \mid \text { Taxable Income }=\sum_{i \in \mathcal{I}} \sum_{p \in \mathcal{P}} Y_{i p k} \\
& - \text { Tax Liability }_{k} \mid \text { Taxable Income }=\sum_{\left\{i^{\prime} \in \mathcal{I}: i^{\prime} \neq i\right\}} \sum_{p \in \mathcal{P}} Y_{i^{\prime} p k}
\end{aligned}
$$

where $i=$ capital gains. ${ }^{14}$ The tax consequences of sequentially zeroing out income of type $i$ for partner $k$ from all partnerships relative to the size of the payment $Y_{i k}$ defines our tax rate $T_{i k}$. This measure accurately accounts for the tax situation of each partner and the full complexity of the tax code imbedded in OTA tax calculators. ${ }^{15}$

For partners who are C-corporations, we assume an average federal payout tax rate (the

\footnotetext{
${ }^{14}$ Due to the sequential treatment of income, the income types included in the sum over income types (when calculating hypothetical income) is not always $i^{\prime} \neq i$. For dividend income, the hypothetical tax liability is based on the following taxable income: Taxable Income $=\sum_{\left\{i^{\prime} \in \mathcal{I}: i^{\prime} \neq \text { capital gains or dividends }\right\}} \sum_{p \in \mathcal{P}} Y_{i^{\prime} p k}$ since dividend income is considered in the sequence after capital gains income.

${ }^{15}$ This approach focuses on allocations of income to partners, but there are important tax implications of allocations of losses and tax credits that can results in different tax rates. We discuss these considerations in section 3.1.4.
} 
tax rate paid by owners on after-corporate-income-tax income) of $8.25 \%$ based on earlier work. ${ }^{16}$ For partners who file other tax forms, we assign the following tax rates:

$$
T_{i k}^{\text {Assigned }}= \begin{cases}T_{i, 1040}^{\mathrm{OTA}} & \text { if } \text { form } \in\{1120-\mathrm{RIC}, 1120-\mathrm{REIT}, 1066,1041\} \\ T_{i, 1120}^{\mathrm{OTA}} & \text { if } \text { form } \in\{1120 j\} \forall j \in\{\mathrm{F}, \mathrm{PC}, \mathrm{L}, \mathrm{H}, \mathrm{C}, \mathrm{POL}, \mathrm{ND}, \mathrm{SF}, \mathrm{FSC}\} \\ .025 & \text { if } \text { form } \in\{8805,1042 \mathrm{~S}, 8288 \mathrm{~A}, 1042\} \\ 0 & \text { if } \text { form } \in\{990,990 \mathrm{j}\} \forall j \in\{\mathrm{T}, \mathrm{R}, \mathrm{PF}, \mathrm{ZR}, \mathrm{C}\} \\ \frac{.025+T_{i, 1120}^{\mathrm{OTA}}}{2} & \text { if } k \text { has unidentified EIN or tin type }\end{cases}
$$

where form is the tax form partner $k$ files, $T_{i, 1040}^{\mathrm{OTA}}$ is the tax rate for individuals from the OTA tax calculator for income type $i$, and $T_{i, 1120}^{\mathrm{OTA}}$ is the tax rate for $\mathrm{C}$-corporations. The $2.5 \%$ rate is set to match the modest revenues from foreign withholding (Luttrell, 2013). We assign tax-exempt entities which file Form-990-family forms a rate of $0 \%$. While we observe a substantial amount of income paid to these entities that could be subject to the Unrelated Business Income Tax, we know from other sources that in fact little is subject to tax and little tax is paid given that in aggregate about $\$ 350$ million in tax is paid by tax exempts on all sources of their business income (Jackson, 2014). Finally, we set the tax rate for unidentified entities to the midpoint of two tax rates: the tax rate for C-corporations and the tax rate for foreign entities. Reconciliations at the end of schedule $\mathrm{K}$ on the 1065 in SOI data suggest that more partnership income is passed to corporate partners than we identify based on traceable entities. However, the income composition earned by untraceable entities more closely resembles the income composition of foreign entities. We use the average of C-corporations and foreign entities to account for both considerations. ${ }^{17}$ We quantify the implications of this approach for the average tax rate on partnership income in section 4.2.

\footnotetext{
${ }^{16}$ To obtain an average tax rate on C-corporation payouts to shareholders, we make three assumptions. First, shareholders receive $50 \%$ of after-corporate-income-tax income as dividends and the other $50 \%$ as accrued capital gains. Second, the average dividend tax rate is $13.2 \%(=18.5 \%$ - the state-plus-federal estimate from Poterba (2004) for 2003-minus 5.3\% - the OECD's average state dividend tax estimate). Third, the accrued capital gains tax rate equals the average dividend tax rate (since the top federal longterm capital gains tax rate equaled the top federal dividend tax rate in 2011) divided by 4 (to account for tax benefits from deferring realizations). These assumptions yield an average payout tax rate of $50 \% \times .132+$ $50 \% \times .132 \times \frac{1}{4}=.0825$ and thus an average C-corporate partner tax rate of $T_{i k}+\left(1-T_{i k}\right) \times .0825$ where $T_{i k}$ is the tax rate from the OTA tax calculator for the first layer of income. This methodology follows work going back to Bailey (1969) and employed recently in Desai and Goolsbee (2004) and Yagan (2015).

${ }^{17}$ We used subsidiary information from form 851 to determine that the vast majority of untraceable income is not associated with income from subsidiaries. See section 4.2 for more information on income composition.
} 


\subsubsection{Tax Rates on Partnerships}

For a given partnership ${ }^{18}$ we use these tax rates $T_{i k p}$ to construct a partnership tax rate:

$$
T_{p}=\left(\frac{\sum_{i \in \mathcal{I}} \sum_{k \in \mathcal{K}} T_{i k} Y_{i k p}}{Y_{p}}\right)
$$

where the numerator $\sum_{i \in \mathcal{I}} \sum_{k \in \mathcal{K}} T_{i k} Y_{i k p}$ is the sum of tax liabilities over income types $i$ and partners $k$ associated with payments from partnership $p$ and the denominator $Y_{p}=$ $\sum_{i \in \mathcal{I}} \sum_{k \in \mathcal{K}} Y_{i k p}$ is the total payments from partnership $p$. Consider the following example. Suppose partnership A has two partners, 1 and 2. Suppose further that partner 1 receives both ordinary income and capital gains and partner 2 only receives ordinary income. The tax rate $T_{A}$ for partnership $A$ is:

$$
\begin{aligned}
T_{A} & =\left(\frac{T_{\text {ordinc }, 1} Y_{\text {ordinc }, 1, A}}{Y_{A}}\right)+\left(\frac{T_{\text {capgains }, 1} Y_{\text {capgains }, 1, A}}{Y_{A}}\right) \\
& +\left(\frac{T_{\text {ordinc }, 2} Y_{\text {ordinc }, 2, A}}{Y_{A}}\right) .
\end{aligned}
$$

This example shows that the distribution across income types for each partner and the distribution across partners are key determinants of tax rates on partnership income.

\subsubsection{Tax Rates on Partnership Sector}

Finally, we construct a tax rate for the partnership sector:

$$
T=\left(\frac{\sum_{i \in \mathcal{I}} \sum_{k \in \mathcal{K}} \sum_{p \in \mathcal{P}} T_{i k} Y_{i k p}}{Y}\right)
$$

where the numerator is the sum of tax liabilities from payments from partnerships and the denominator $Y=\sum_{i \in \mathcal{I}} \sum_{k \in \mathcal{K}} \sum_{p \in \mathcal{P}} Y_{i k p}$ is the total payments from all partnerships.

\subsubsection{Discussion of Assumptions}

We could have calculated the tax rate as the 'last dollar' average rate, the 'first dollar' average rate, or the 'first dollar of business income rate.' In evaluating policy changes (including revenue estimating settings), the 'last dollar' rate is often the most appropriate measure. If one is considering an individual's decision whether to participate in a partnership

\footnotetext{
${ }^{18}$ See appendix A for a discussion of how we calculate tax rates for tiered partnerships for analysis at the partnership level.
} 
the 'first dollar of business income' may be preferable. Our measure has the advantage of being straightforward to calculate and provides a reasonable way to calculate both the total tax paid for a particular partnership and the average tax rate on the income flows of the partnership sector overall.

In addition, it is possible that partnerships distribute different types of payments differently. For instance, gains and losses or tax deductions need not be symmetrically allocated to partners. Different assumptions about asymmetries in distributions could result in different tax rates. ${ }^{19}$ In addition, we do not model passive loss limits for individuals.

Furthermore, we focus only on income taxes. A portion of partnership income may be subject to SECA tax but we do not observe self-employment income on the partner's K-1 and the Schedule SE may include income from partnerships, sole proprietorships and other forms To the extent SECA tax is due on partnership income, a SECA deduction for the partner will be generated which ideally we would zero out along with the partnership income. As a result the calculated partnership tax rates for some individual partners are slightly misstated. Finally, we also assume that all dividends are taxed at preferential rates.

\subsection{Sole Proprietorship Income}

We calculate tax rates on Sole Proprietorship income using SOI's sample of individual tax returns. Specifically, we measure the difference between actual taxes paid and hypothetical taxes paid when we set income from schedule C and SECA deductions to zero using OTA's individual tax model. ${ }^{20}$

\subsection{S-Corporation Income}

We calculate tax rates on S-corporation income using OTA tax calculators. First, we measure the difference between actual taxes paid and hypothetical taxes paid when we set Scorporation income from Form 1120S Schedule K-1 to zero. Second, we divide this change in tax liability by total Form $1120 \mathrm{~S}$ K-1 income to estimate the tax rate on S-corporation income.

\footnotetext{
${ }^{19}$ Assumptions are required because not all fields (especially certain deductions and credits) are included in our population-level pass-through income data.

${ }^{20}$ We ignore payroll taxes except for the loss of the SECA deduction, which is listed as an above-the-linededuction as opposed to being claimed on the schedule C.
} 


\subsection{C-Corporation Income}

There are two layers of taxation on C-corporation income. The first layer relates to the corporate tax. The second layer relates to dividend taxes paid on distributions to the owners. We divide actual taxes paid by taxable income to determine the average tax rate on the first layer of taxation on corporate income. ${ }^{21}$ We use the estimate from Poterba (2004) on the average tax rate on the dividend income to determine the second layer. ${ }^{22}$ We then sum the tax rates on the first and second layers to obtain an estimate of the average tax rate on C-corporation income.

\section{Average Tax Rates on Business Income}

We estimate that the average tax rate on business income in 2011 is $24.3 \%$. This rate is an income-weighted average of business tax rates. In section 4.1, we compare tax rates across the business forms and industries that contribute to the overall average. In section 4.2, we investigate and decompose tax rates on partnerships, which are a key determinant of lower tax rates on business income. In section 4.3, we calculate the importance of the rise of pass-throughs on the average tax rate on business income. Finally, we calculate the tax rate on business income including debt in section 4.4.

\subsection{Comparison of Tax Rates Across Business Form and Industry}

Figure 7 shows the average tax rates by business form. We estimate that the overall tax rate in 2011 on partnerships was $15.9 \%$. Tax rates on the partnership sector are comparable to those on the informal sector and are lower than the tax rates on both S-Corporations by 9.1 percentage points and C-corporations by 15.7 percentage points.

Figure $8 \mathrm{~A}$ shows the average tax rates by type of partner. S-corporations, individuals, and C- and other corporations face the highest rates at $22.0 \%, 21.0 \%$, and $20.1 \%$, respectively. Estates and trusts pay $16.5 \%$ on average. For other partner types, we plot the assumed tax rates as described in section 3.1.1.

To compute tax rates for each partnership, it is necessary in many cases to follow income through multiple tiers of ownership until it reaches a taxable end point, and then assign

\footnotetext{
${ }^{21}$ Note that taxable income for C-corporations is total income reported for U.S. tax purposes, which includes income from partnerships.

${ }^{22}$ We use the same approach that we take for C-corporate partners, i.e., as described in footnote 16, we compute tax rates for C-corporations as $\tau+(1-\tau) \times \frac{5}{8} \times .132$ where $\tau$ is the tax rate on the first layer of income. Note that we use $13.2 \%$ instead of $18.5 \%$ since we focus on the federal rather than the federal plus state portions of the estimate in Poterba (2004).
} 
that income back to an originating partnership. Figure 3B shows that $26.3 \%$ of income flows from partnerships to other partnerships and thus must be followed through. The algorithm for implementing this procedure is detailed in appendix A. We follow income from partnership to partnership through the levels of ownership until the algorithm reaches a fixed point, which allows us to uniquely assign $85.1 \%$ of non-partnership income flows to a distinct partnership. The remaining $14.9 \%$ cannot be assigned this way. Because the K-1 reports the income amounts by income type and the partner type, we can still calculate a tax rate for this unassigned income. For this unassigned income, we calculate a tax rate of $8.8 \%$, considerably lower than the $15.9 \%$ overall rate on partnership income.

Figure 9A shows the average tax rates by partnership industry for the partnerships where we can allocate all income associated with them. Finance and holding company income, which accounts for $70.0 \%$ of partnership income, is taxed at a $14.7 \%$ rate on average. This is the lowest rate among industries with nontrivial amounts of activity. Manufacturing and mining, oil, and gas follow at $16.6 \%$ and $18.5 \%$, respectively. The traditional partnership industries, professional services at $22.4 \%$ and health care at $22.3 \%$, pay the highest rates.

\subsection{Decomposing the Tax Rate on Partnership Income}

There are three main reasons why the tax rate on partnership income could be relatively low: (1) partnership income may be distributed via income types with low tax rates, (2) partnership income may be earned by partners that face low tax rates, and (3) flexible allocation rules might allow losses to be passed on to partners with high rates and gains to those with low rates. Related to the third reason is the possibility that tiering and complex structures allow losses in one partnership to offset gains in another, or that these structures create circular income flows that we do not observe leaving the partnership sector.

We find support for the first two explanations. Roughly one quarter of partnership income is earned by taxpayers facing a zero rate. Nearly half of partnership income allocated to taxable entities accrues in the form of tax preferred capital gains and dividends. We find mixed evidence that losses are disproportionately allocated to partners with high tax rates. Complex structures do coincide with relatively low rates but are not large enough to account for the low overall rate.

Payments via Low Tax Income Types. Figure 8B presents a decomposition of partnership income by income type for each type of partner. The figure illustrates a key reason why the partnership rate is low: capital gains and dividend income, both typically taxed at preferred rates, represent $45 \%$ of total income that accrues to non-partnership partners. 
The share of capital gains and dividend income varies by type of partner, with tax exempts and foreigners primarily receiving capital gains and dividend income while the S-corporation and individual capital income shares are significantly lower. Note that the income shares for the unidentified partner types most closely resemble a mix between the foreign entity and C-corporation income shares. This fact forms the basis of our tax rate assumptions for these unknown partners.

Figure 9B presents a decomposition of partnership income by income type based on partnership industry. This figure shows that finance and holding company firms earn nearly sixty percent of their income as capital gains and dividends, while other industries earn the bulk of their income as ordinary income.

Partners with Low Tax Rates. The distribution of income types is an important reason for the low overall partnership rate, but it is not the only reason. For example, while manufacturing and oil and gas partnerships earn most of their income as ordinary income, they pay only somewhat higher rates than finance partnerships.

A second reason why the tax rate on partnership income can be low relates to the level of tax rates faced by partners. Foreign partners, tax exempt partners, or lower-income partners face low tax rates $T_{i k}$ on any income type that they earn. Payment shares of total partnership income to foreign partners is $9.3 \%$, tax-exempt partners is $5.5 \%$. Unidentified partner types earn another $20.1 \%$ of partnership income. Were these partners to be taxed at the average individual tax rate, the average rate on partnership income would rise by approximately 2 percentage points.

Tiering and Flexible Loss Allocation Rules. Tiering and flexible allocation rules are a third set of reasons why the average tax rate on partnership income could be low relative to traditional businesses. If multiple partnerships are connected, it may be possible for losses in one partnership to offset gains in another, such that gains are mainly realized for low tax rate partners. Partnership income accruing to other partnerships amounts to $26.3 \%$ of total income flows, so there may be wide scope for across-partnership offsetting to occur. Even among partnerships without partnership partners, losses may be allocated to partners with high marginal tax rates and gains may be allocated to partners with low marginal tax rates.

In addition to its role in generating low rates, the extent of partnership tiering presents major challenges from a tax administration perspective. After our recursive algorithm reaches a fixed point, there remain 22,417 "circular" partnerships for which we cannot uniquely link all income to non-partnership owners. These partnerships issue 9.6 million K-1s. To put this activity's scale in perspective, our entire K-1 population file includes 25.5 
million K-1s issued by 3.6 million partnerships. Thus, less than $1 \%$ of partnerships issue nearly $40 \%$ of K-1s. Some of these partnerships issue more than 100,000 K-1s.

We divide the $\$ 671$ billion of income reported on K-1s for non-partnership owners based on whether the K-1s were issued by a solved or circular partnership. $\$ 100$ billion remains within the nexus of the 22,417 circular partnerships. Were we to collapse all of these partnerships into one partnership and estimate the tax rate based on the tax paid on income received by their non-partnership partners, they would pay a rate of $8.8 \%$. This $8.8 \%$ tax rate is roughly half the tax rate paid on the remaining $\$ 571$ billion, which amounts to $17.1 \%$. This evidence suggests that tax planning benefits associated with complex structures may contribute to the low overall rate.

To explore the importance of flexible loss allocation rules, Figure 10 plots the share of total losses and the share of total gains claimed by the partnerships grouped by partner tax rates. Losses tend to be allocated disproportionately to partners with tax rates above $30 \%$. However, payments facing relatively high tax rates between 20 and $30 \%$ are more likely to represent gains than losses. Overall, the patterns in partner payment allocation provide mixed evidence that flexible allocation rules contribute to the low average tax rate on partnership income.

\subsection{Tax Rate on Business Income without Pass-throughs}

This section quantifies the importance of the rise of pass-throughs on the average tax rate on business income.

In 2011, C-corporations earned $45.4 \%$ of business income and sole proprietorships earned $12.5 \%$. We allocate pass-through income from partnerships and S-corporations, which amounted to $25.6 \%$ for partnerships and $16.5 \%$ for S-corporations, to C-corporations and sole proprietorships in proportion to 1980 income shares.

We find that allocating partnership income to traditional businesses results in an average tax rate on business income of $28.1 \%$, which exceeds the average tax rate on business income of $24.3 \%$ in 2011 by 3.8 percentage points. Since the pass-through sector earned $\$ 1.1$ trillion in business income in 2011, an additional 3.8 percentage points on the tax rate would have generated 97 billion more dollars in business tax revenue, which would amount to an approximately $15.5 \%$ increase in tax revenues from business income on an annual basis. ${ }^{23}$

We stress that this exercise is not a projection for the likely effects on tax revenue from business tax reform. It is mechanical and assumes no behavioral responses, but has the

\footnotetext{
${ }^{23}$ We compute the aggregate pass-through figure of $\$ 1.1$ trillion by scaling partnership income of $\$ 671$ billion by the ratio of the total pass-through income share to the partnership income share (equal to (.165+ $.256) / .256)$. These shares come from figure 1 of DeBacker and Prisinzano (2015).
} 
advantage of being transparent. ${ }^{24}$

\subsection{Overall Tax Rate on Business Income including Debt}

This section calculates the overall tax rate on business income including interest income. This overall tax rate $\tau_{K}$ is an income-weighted average of business income and interest deductions.

$$
\tau_{K}=\left(\frac{Y_{e}}{Y_{e}+Y_{d}}\right) \tau_{e}+\left(\frac{Y_{d}}{Y_{e}+Y_{d}}\right) \tau_{d}
$$

where $Y_{e}$ is business income, $Y_{d}$ is the sum of interest deductions, $\tau_{e}$ is the tax rate on business income and $\tau_{d}$ is the tax rate on interest income. ${ }^{25}$

Business income $Y_{e}=\$ 2.6$ trillion in $2011 .{ }^{26}$ We compute interest income in the business sector by summing interest deductions claimed on forms 1120, 1120S, and 1065. Summing these deductions amounts to $Y_{d}=\$ 809$ billion.

We use the average tax rate on business income from section 4 for $\tau_{e}=24.3 \%$. We compute the tax rate on interest income $\tau_{d}$ by zeroing out interest income and recomputing tax liabilities using OTA tax calculators (in a similar fashion to the rates underlying $\tau_{e}$ ).

In particular, we calculate $\tau_{d}$ as the average income tax rate on interest income and non-qualified dividend income (which is typically interest). For both types of income, we calculate the tax consequences of zeroing out that income type. We find that removing interest income reduces tax liabilities by $20.6 \%$ of interest income and removing non-qualified dividend income reduces tax liabilities by $20.1 \%$ of non-qualified dividend income. Weighed by the shares of income, the average income tax rate on interest income $\tau_{d}$ equals $20.4 \%$.

We weigh these rates to calculate an overall tax rate on business income that includes debt:

$$
\tau_{K}=\left(\frac{2.6}{2.6+0.8}\right) 24.3 \%+\left(\frac{0.8}{2.6+0.8}\right) 20.4 \%=.76 \times 24.3 \%+.24 \times 20.4 \%=23.3 \%
$$

\footnotetext{
${ }^{24}$ Furthermore, it maintains consistency with the rest of this paper by using the same underlying data, at the cost of those data's missing fields and top-coding (see section 1 for a discussion of data limitations that introduce deviations between our aggregates and official aggregates.)

${ }^{25}$ Note that $\tau_{K}$ is for the business sector as opposed to the tax rate on capital income. Our measure does not include housing income.

${ }^{26}$ This calculation scales partnership income by its share of overall business income, i.e., $\$ 671$ billion/.256.
} 


\section{Conclusion}

Most U.S. business income is now earned outside the traditional C-corporate and sole proprietorship sectors and is instead earned in the pass-through sectors. This income is taxed at the owner-level and often at low rates. We used 2011 tax returns to trace pass-through income in the two major pass-through sectors - the partnership sector and the S-corporate sector - to their ultimate owners to document who owns U.S. businesses and how much U.S. tax do those owners pay.

We found that pass-through owners are even more likely to be high-earners than the owners of other business types including C-corporations. Holding all other sectors' income constant, we estimated an average partnership sector tax rate of 15.9\%: for ever dollar earned by a partnership, U.S. tax revenue rose by $\$ 0.159$. For the S-corporate sector, we estimated an average tax rate of $25.0 \%$, yielding an average pass-through (partnership-plusS-corporate) tax rate of $19.5 \%$. Combining these rates with our estimated C-corporate rate $(31.6 \%)$ and sole proprietorship rate $(13.6 \%)$, we estimated an overall U.S. federal tax rate on U.S. taxable business income of $24.3 \%$ - much lower than the top statutory personal (35\%) and C-corporate (35\% income plus additional payout) rates.

The migration of business activity out of the C-corporate sector and into the pass-through sector has likely substantially reduced U.S. tax revenue. If 2011 business income had instead been earned along 1980 sector income shares, we estimated under strong but straightforward assumptions that the average tax rate on U.S. business income would have been $28 \%$, yielding an extra $\$ 100$ billion in tax revenue.

This paper's analysis can be extended in at least three important directions. First, business activity varies considerably across sectors; for example, most hedge funds are partnerships. It would therefore be valuable to estimate average tax rates across organizational form holding business activity constant. Second, firms' investment and location decisions depend on worldwide tax rates on worldwide income, which would likely be substantially smaller than the the U.S. tax rates on U.S. income estimated here. Broadening tax and income definitions to encompass non-repatriated income (reported on Forms M-3 and 5471) is an exercise left to future work. Third, inclusion of missing fields (especially certain deductions and credits) in our population-level pass-through income data would permit more complete tax rate estimates.

Finally, we note that a long-standing rationale for the entity-level corporate income tax is that it can serve as a backstop to the personal income tax system (e.g., Bank (2010), Zucman (2014)). Our inability to unambiguously trace $30 \%$ of partnership income to either the ultimate owner or the originating partnership underscores the concern that the current U.S. 
tax code encourages firms to organize opaquely in partnership form in order to minimize tax burdens. Historically, policymakers in the 1930s reduced the prevalence of opaque business structures ("pyramids") in the traditional corporate sector by instituting the intercorporate dividend tax (Morck, 2004). Whether policymakers should pursue a similar approach today remains an open question. 


\section{References}

Altshuler, Rosanne, Alan Auerbach, Michael Cooper, and Matthew Knittel. 2009. "Understanding U.S. Corporate Tax Losses." Tax Policy and the Economy, 23: 73-122.

Auerbach, Alan J. 1983. "Corporate taxation in the United States." Brookings Papers on Economic Activity, 451-513.

Auerbach, Alan J., and James M. Poterba. 1987. "Tax loss carryforwards and corporate tax incentives." In The effects of taxation on capital accumulation. 305-342. University of Chicago Press.

Bailey, Martin J. 1969. "Capital Gains and Income Taxation." The Taxation of Income from Capital, , ed. Martin J Bailey and Arnold C Harberger, 11-49. The Brookings Institution.

Bank, Steven A. 2010. From Sword to Shield: The Transformation of the Corporate Income Tax, 1861 to Present. Oxford University Press.

Bull, Nicholas, Robin Fisher, and Susan Nelson. 2009. "Characteristics of Business Ownership: Overview for Pass-through Entities and Evidence on S Corporate Ownership from Linked Data."

Carroll, Robert, and David Joulfaian. 1997. "Taxes and corporate choice of organizational form." US Department of the Treasury, OTA Paper, 73.

DeBacker, Jason M., and Richard Prisinzano. 2015. "The Rise of Partnerships." Tax Notes, 147(13): 1563-75.

Desai, Mihir A., and Austan D. Goolsbee. 2004. "Investment, overhang, and tax policy." Brookings Papers on Economic Activity, 35(2): 285-355.

Feldstein, Martin, and Lawrence Summers. 1977. "Is the rate of profit falling?" Brookings Papers on Economic Activity, 211-228.

Gordon, Roger H., and Joel Slemrod. 2000. "Are 'real' responses to taxes simply income shifting between corporate and personal tax bases?" Does Atlas Shrug? The Economic Consequences of Taxing the Rich, , ed. Joel Slemrod. Russell Sage Foundation and Harvard University Press. 
Gordon, Roger H, James R Hines, and Lawrence H Summers. 1987. "Notes on the tax treatment of structures." In The effects of taxation on capital accumulation. 223-258. University of Chicago Press.

Gravelle, Jane G., and Laurence J. Kotlikoff. 1989. "The incidence and efficiency costs of corporate taxation when corporate and noncorporate firms produce the same good." Journal of Political Economy, 749-780.

Harberger, Arnold C. 1962. "The incidence of the corporation income tax." Journal of Political Economy, 215-240.

Jackson, Jael. 2014. "Unrelated Business Income Tax Returns, 2010." Statistics of Income Bulletin.

Kaplan, Steven N., and Joshua Rauh. 2010. "Wall Street and Main Street: What contributes to the rise in the highest incomes?" Review of Financial Studies, 23(3): 10041050.

Knittel, Matthew J., and Susan C. Nelson. 2011. "How Would Small Business Owners Fare under a Business Entity Tax?" National Tax Journal, 64(4): 949-75.

Luttrell, Scott. 2013. "Foreign Recipients of U.S. Income, 2010." Statistics of Income Bulletin.

May, Larry. 2012. "Using Link Analysis To Identify Indirect and Multi-Tiered Ownership Structures." 2012 IRS-TPC Research Conference http://www. irs. gov/uac/ SOI-Tax-Stats-2012-IRS-TPC-Research-Conference.

Morck, Randall. 2004. "How to Eliminate Pyramidal Business Groups: The Double Taxation of Inter-Corporate Dividends and Other Incisive Uses of Tax Policy." Tax Policy \&5 the Economy, 19: 2013-610.

Pearce, James. 2014. "Aggregate Business Income." OTA Working Paper.

Piketty, Thomas, and Emmanuel Saez. 2003. "Income Inequality in the United States, 1913-1998." Quarterly Journal of Economics, 118(1): 1-41.

Piketty, Thomas, and Emmanuel Saez. 2014. "Income Inequality in the United States, 1913-1998 (Updated through 2012)." Quarterly Journal of Economics, 118(1): 1-41.

Poterba, James. 2004. "Taxation and Corporate Payout Policy." American Economic Review, 94(2): 171-175. 
Saez, Emmanuel. 2014. "Income and Wealth Inequality: Evidence and Policy Implications." http: // eml. berkeley. edu/ saez/lecture_saez_chicago14. pdf.

Saez, Emmauel. 2004. "Reported incomes and marginal tax rates, 1960-2000: Evidence and policy implications." In Tax Policy and the Economy, Volume 18. 117-174. MIT Press.

Slemrod, Joel. 1996. "High-income families and the tax changes of the 1980s: the anatomy of behavioral response." In Empirical foundations of household taxation. 169-192. University of Chicago Press.

Suárez-Serrato, Juan Carlos, and Owen M Zidar. 2014. "Who Benefits from State Corporate Tax Cuts? A Local Labor Markets Approach with Heterogeneous Firms." NBER Working Paper No. 20289.

Yagan, Danny. 2015. "Capital Tax Reform and the Real Economy: The Effects of the 2003 Dividend Tax Cut." American Economic Review.

Zucman, Gabriel. 2014. "Taxing across Borders: Tracking Personal Wealth and Corporate Profits." The Journal of Economic Perspectives, 121-148.

Zwick, Eric, and James Mahon. 2014. "Do Financial Frictions Amplify Fiscal Policy? Evidence from Business Investment Stimulus." Working paper. 


\section{A Appendix}

\section{A.1 Calculating Partnership Tax Rates}

Our calculation for the tax rate on the overall partnership sector uses equation 3.6 as described in section 3.1.3. That rate is based only upon the tax liabilities of non-partnership partners on their partnership incomes. Our partnership-level tax rates are consistent with this overall tax rate and account for tiering of partnerships. These calculations require that each partner in the partnership, including other partnerships, be assigned a tax rate for each type of income (schedule E, capital gains, interest, and dividends). An overall tax rate for a partnership requires weighting these rates using only the income generated by the partnership after removing any income received from other partnerships. This insures that double-counting of dollars does not occur and attributes income to the partnership that generated the income as opposed to the partnership that received it. The implicit assumption in this method is that the tax rate by partners on a specific source of income applies to both income generated by the partnership and income received from other partnerships. For example, assume partnership A disburses $\$ 100$ in capital gains income to its partners, $\$ 50$ of which is created by partnership A and $\$ 50$ of which it receives via a K-1 from partnership B. If the partners of partnership A pay $15 \%$ in tax on this $\$ 100$ of capital gains, we assume that the $15 \%$ rate applies both to the $\$ 50$ created by partnership A and the $\$ 50$ it receives from partnership B.

The process of assigning tax rates for each type of income to each type of partner is described in the body of the paper for all partners that are not partnerships. We refer to partnerships where every partner has a tax rate as "solved" and all other partnerships as "unsolved." For partnerships with no partners that are partnerships, solving its four tax rates is simple. Each partner is either assigned rates for each income type based solely on its filing form or rates are calculated using a tax calculator for the form type. These simple partnerships make up $85 \%$ of the 3.4 million partnerships in our sample. Unfortunately they only account for $\$ 381$ billion of the total $\$ 895$ billion of partnership income (which includes income owing to other partnerships). Thus solving the remaining partnerships is critical for answering questions about the tax burden on individual partnerships.

Once the simple partnerships have been assigned tax rates for each of the four types of income, we define a procedure for recursively solving tax rates for partnerships that are part of dependent partnership structures, meaning that they have partners that are partnerships. If a partnership has only simple partnerships below it, its various tax rates can be assigned as described above for simple partnerships. As mentioned above, an overall tax rate for each partnership requires weighting its four rates using only the income generated by the 
partnership after removing any income received from other partnerships to prevent doublecounting dollars. These one-level partnership structures are then used to calculate tax rates for two-level dependent structures. These structures include partnerships whose partnership partners are either simple partnerships or one-level partnerships. This recursive process is repeated on multi-level structures until each partnership is assigned a tax rate. Each partnerships tax rates can then be weighted by the income it generates to calculate the overall partnership sector tax rate calculated via equation 3.6.

The algorithm is implemented as a series of merges. The K-1s list taxpayer identification numbers (TIN) for the payees and we merge the K-1 file back onto itself by joining where payer TIN equals payee TIN. We use the partnership return's DLN to identify the partnership being solved. Where there are multiple DLNs associated with a single payer TIN, we sort the data set and use the first DLN for that payer TIN.

The first step reduces the number of unsolved partnerships from 503,943 to 187,197 and the amount of income in unsolved partnerships from $\$ 513$ billion to $\$ 392$ billion. Another step reduces the count to 93,684 and the income to $\$ 329$ billion. By the fifth step, the algorithm begins to slow down and we still have 36,338 unsolved partnerships and $\$ 247$ billion in unsolved income. By step ten, we still have 23,757 unsolved partnerships and $\$ 207$ billion in unsolved income. The algorithm reaches a fixed point at step twenty-two, at which point we have 22,417 unsolved partnerships and $\$ 203$ billion in unsolved income (including income owing to other partnerships. These unsolved partnerships issue 9.6 million (nearly forty percent) of the 25.2 million K-1s in our population file. Collapsing all of these partnerships into one and calculating the tax rate based on the tax paid on income received by their non-partnership partners yields that, as a group, they pay a rate of $8.8 \%$ on $\$ 100$ billion on total income.

\section{A.2 Illustrative Example of Circular Structure}

To illustrate further why it is not possible to assign rates to individual partnerships in the unsolved cases, consider the following simple example. In figure A.1, each triangle represents a partnership; each line represents the direction of a K-1. In this example, partnerships A, $\mathrm{B}$ and $\mathrm{C}$ can each be assigned an effective rate. Partnership $\mathrm{A}$ has no partners that are also partnerships. As such, it is straightforward to assign an effective rate to A using our tax rate calculators. Since partnership A is a partner in partnerships B and C, their effective rates can only be assigned after $\mathrm{A}$ is assigned an effective rate since the rates are dependent upon the weighted rates of each partner. It is also the case that since partnership B is a partner in partnership $\mathrm{C}$, the effective rates for $\mathrm{B}$ and $\mathrm{C}$ must be assigned sequentially. 
In figure A.2, we present a circular relational structure, which would fall in the unsolved group our algorithm identifies. Partnership D is a partner in partnership E, partnership $\mathrm{E}$ is a partner in partnership $\mathrm{F}$, and partnership $\mathrm{F}$ is a partner in $\mathrm{D}$. These partnerships cannot be assigned an effective rate. In the case of $\mathrm{D}$, it could be assigned a rate if a rate is assigned to E. However, E's rate is dependent upon a rate being assigned to $\mathrm{F}$ which is in turn dependent upon a rate for D.

Figure A.1: Tiered and Solved Partnership Example

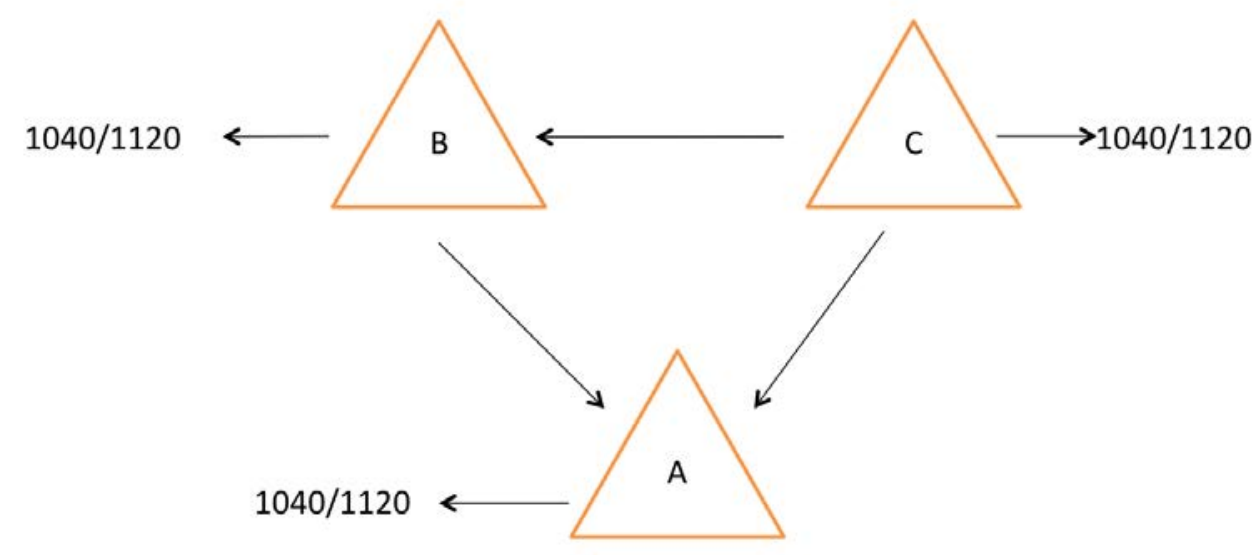

Figure A.2: Tiered and Unsolved Partnership Example

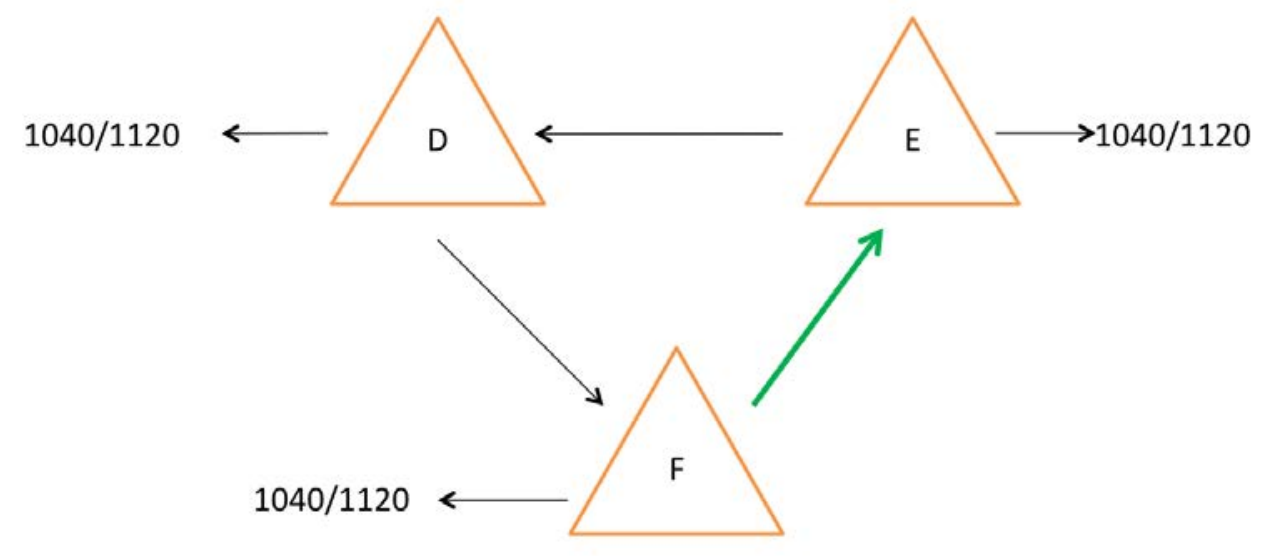


Figure 1: Shares of Business Income by Entity Type, 1980-2010

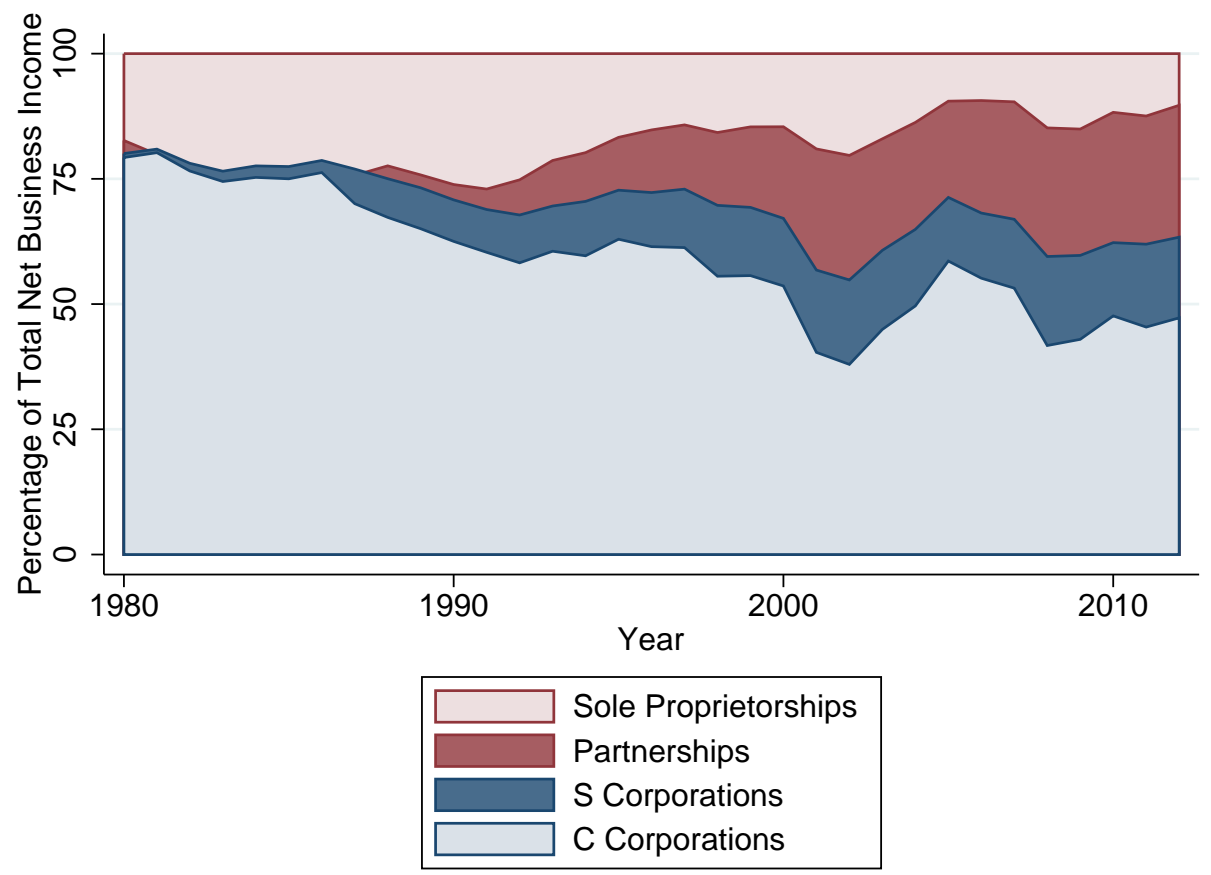

Notes: This figure shows the share of overall business income by entity types from 1980 to 2012 from DeBacker and Prisinzano (2015). 
Figure 2: Role of Pass-Through Income in Rising Top-1\% Income Share
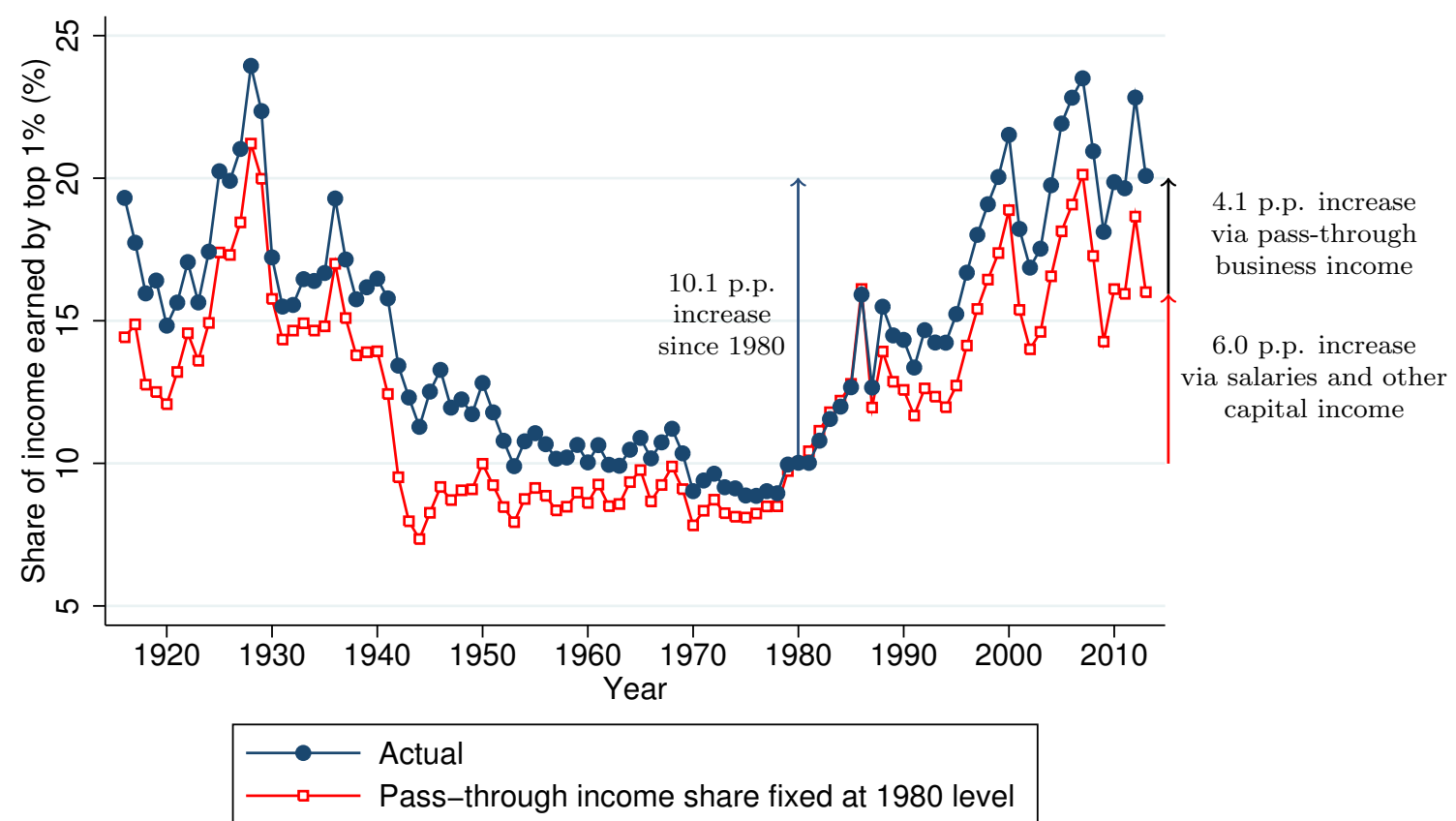

Notes: This figure uses data from Piketty and Saez (2003) to plot estimates of the income of households in the top-1\% of the income distribution as a fraction of total income for years 1916-2013, under two scenarios. In blue circles, we plot actual top income share estimates from Piketty and Saez (2003), including capital gains and updated through 2013 (Piketty and Saez, 2014). In red squares, we plot hypothetical top income share estimates where we hold top-1\% "entrepreneurial" income (predominately pass-through income since 1980 but also including Schedule C and farm income) as a share of total income fixed at its 1980 level of $1.0 \%$ in every year (in contrast, for example, to the actual 2013 level of 5.0\%) -while allowing other top-1\% income (salaries, dividend income, interest income, and capital gains) as a share of total income to evolve as it actually did. These data define income as the sum of Form-1040 "total income" (i.e. adjusted gross income before the adjustments) minus Form-1040 transfer income (social security and unemployment benefits). Total income is defined as the sum of this 1040-based income measure across all 1040-filers plus imputed non-filer income (equal to an assumed share of mean 1040-filer income that varies by year). See Piketty and Saez (2003) for further documentation, and see our footnote 2 for interpretation. 
Figure 3: Partnership K1s and Income Shares by Type of Partner
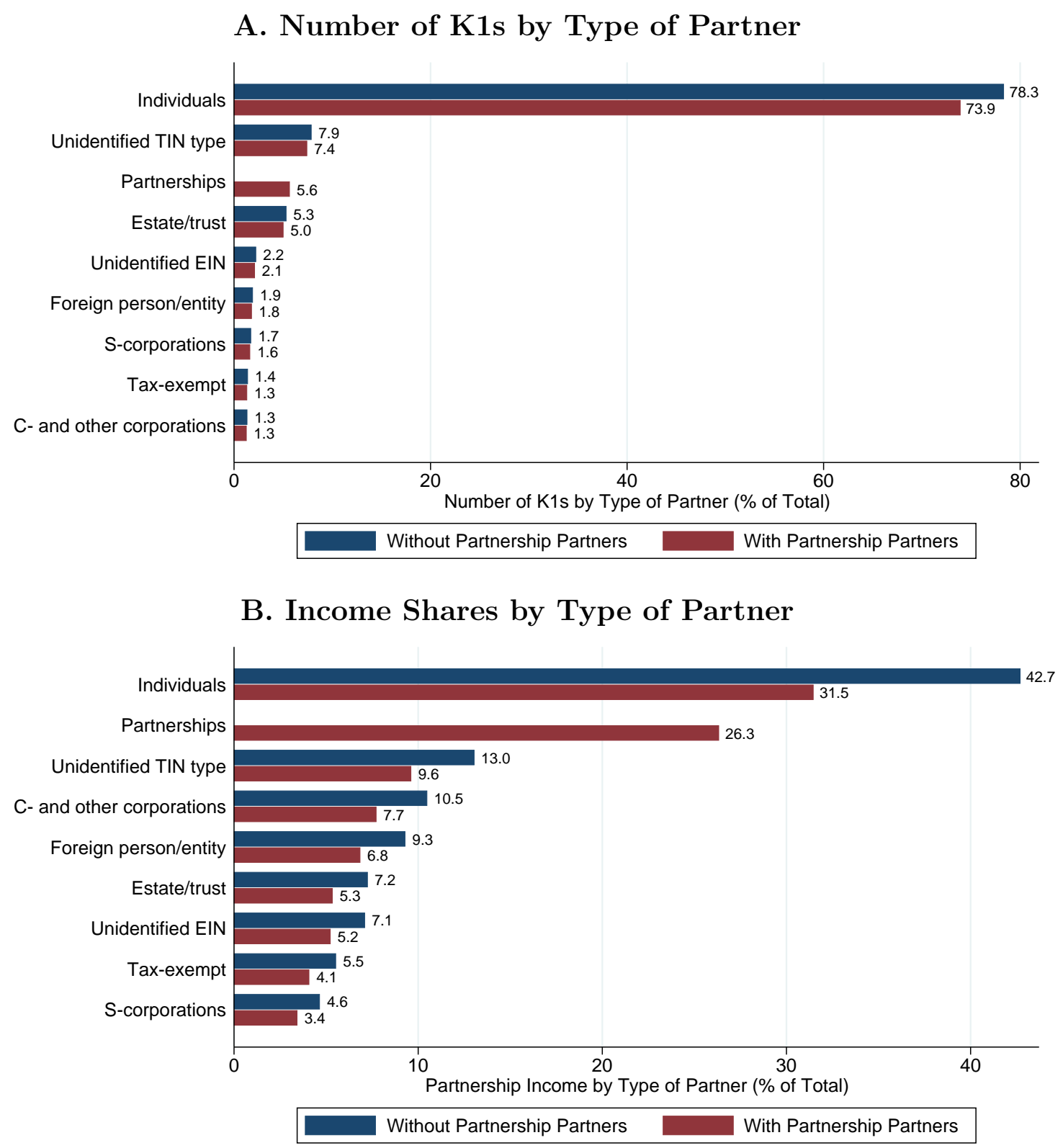

Notes: Panel A shows the equal-weighted distribution of partnership owners by type of partner. We divide the number of K1s received for each partner type by the total number of K1s received across all types. We compute these shares both including and excluding K1s received by other partnerships. Panel B shows the income-weighted distribution of partnership owners by type of partner. We divide total partnership income for each partner type by total partnership income received across all types. We compute these shares both including and excluding K1s received by other partnerships. See section 1.1 for a correspondence between the partner types and tax forms filed. 
Figure 4: Distribution of Partnership Income by Industry

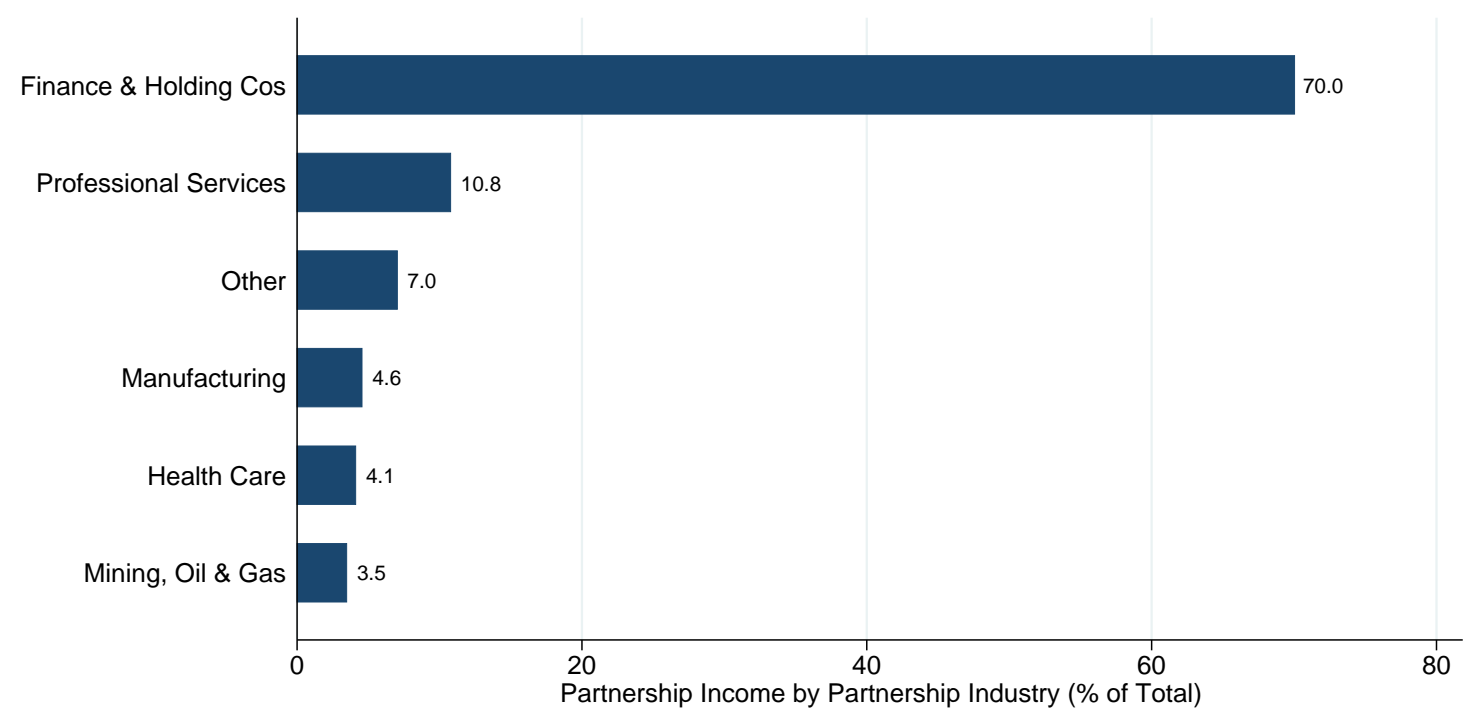

Notes: This figure shows the distribution of partnership income across partnership industry. We divide total partnership income received for partnerships in each industry by total partnership income received. These shares exclude income received by other partnerships. Industry groupings and NAICS codes are as follows: Finance \& Holding Cos (NAICS 52, 55, and 531); Professional Services (NAICS 54); Manufacturing (NAICS 31, 32, and 33); Health Care (NAICS 62); Mining, Oil, \& Gas (NAICS 21). 
Figure 5: Business Participation Rates by Household Income Percentile
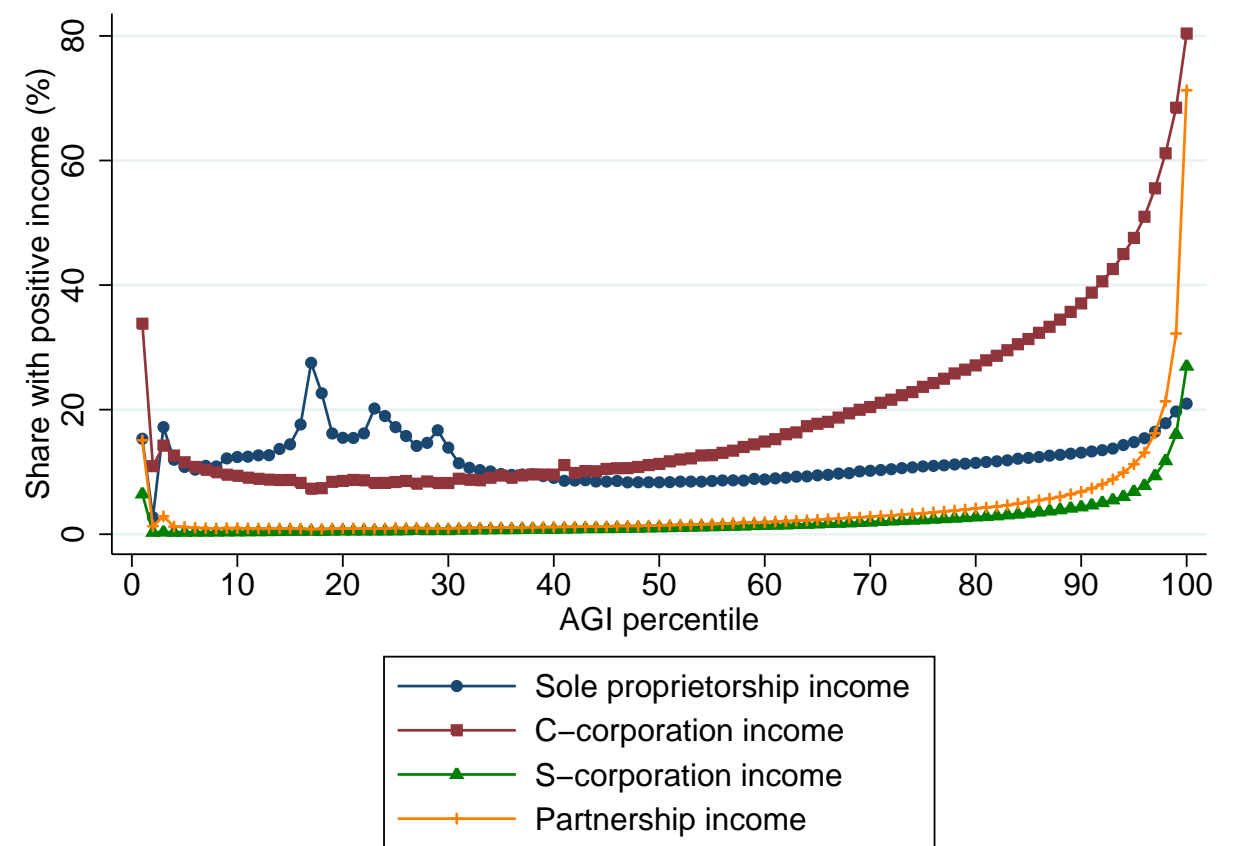

Notes: This figure plots the share of 2011 tax-filing households by percentile of adjusted gross income with positive sole proprietorship income, positive C-corporation and foreign dividend income, positive Scorporation income, or positive partnership income, respectively. 
Figure 6: Business Income Shares by Household Income Percentile

\section{A. Four Types of Business Income}

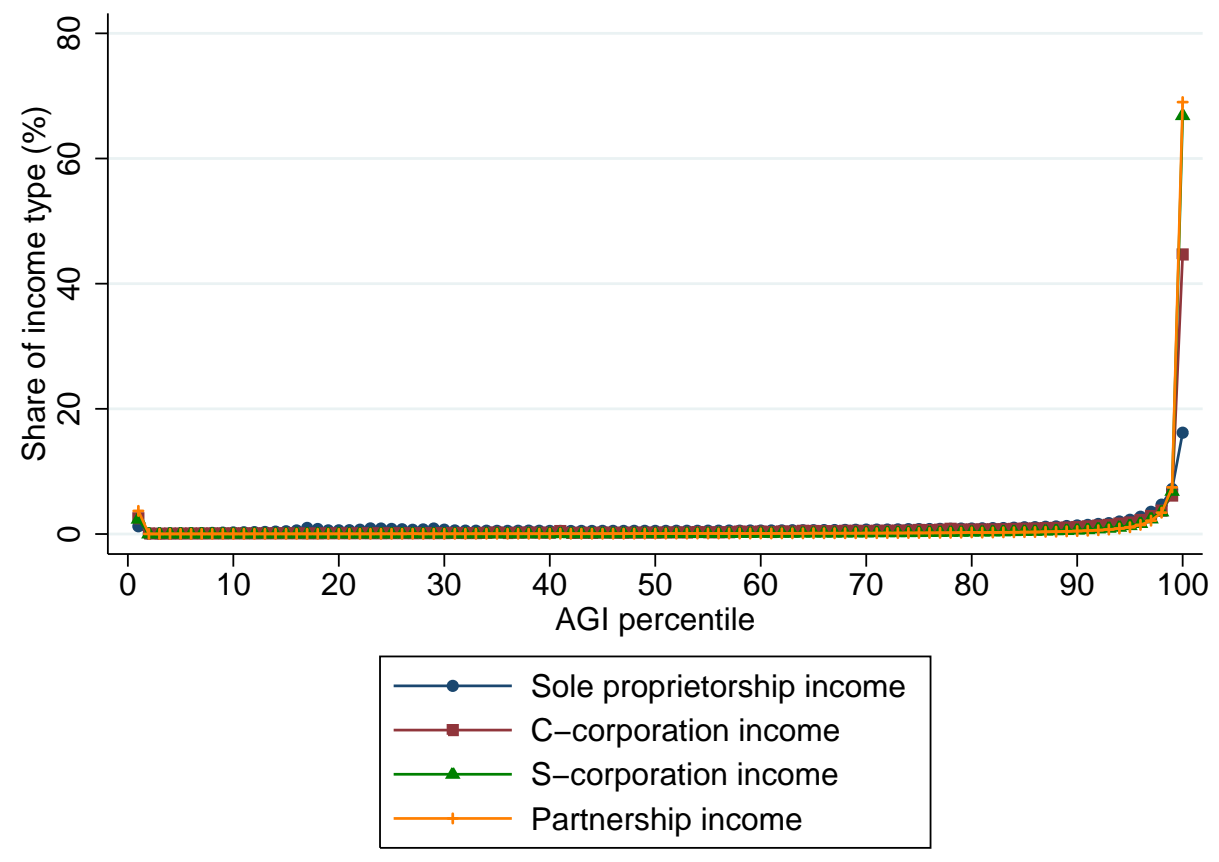

\section{B. Partnership Income of Three Sample Industries}

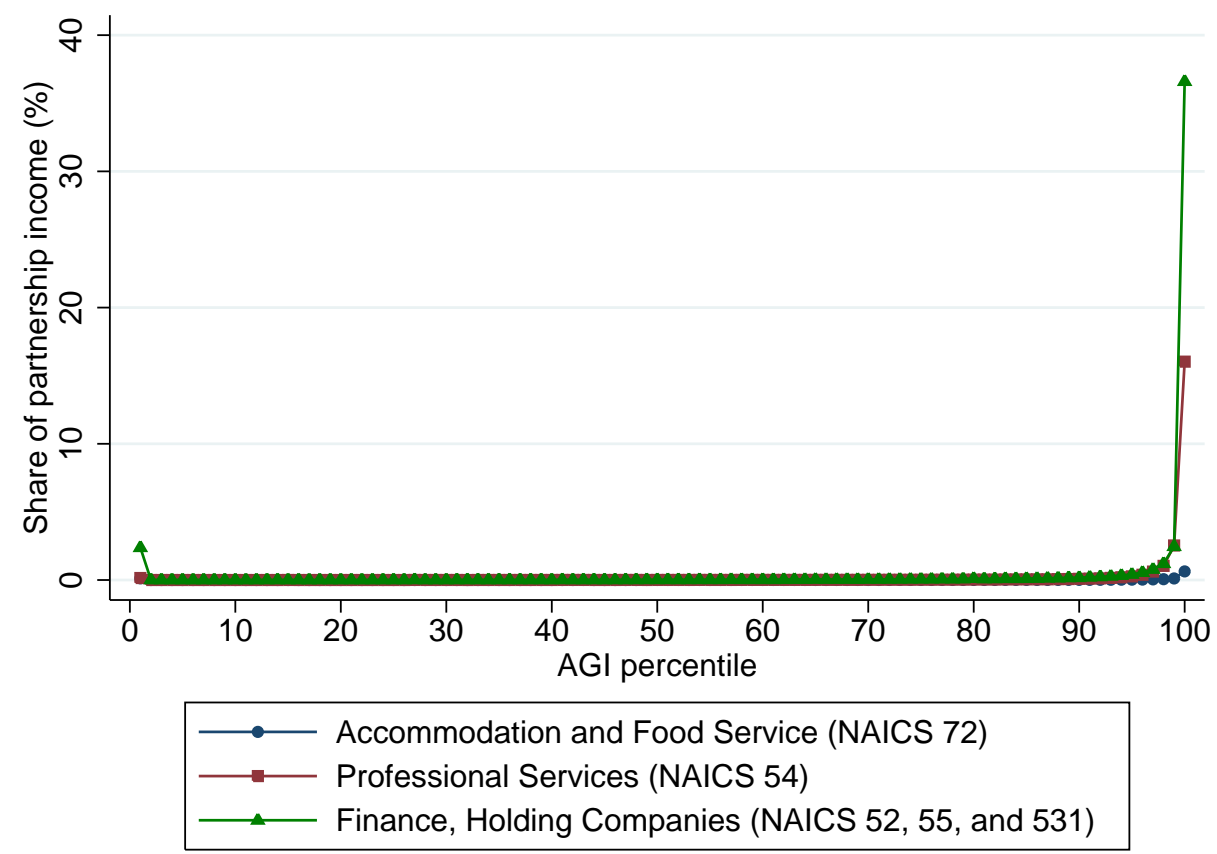

Notes: Panel A plots the 2011 shares of positive sole proprietorship income, positive C-corporation and foreign dividend income, positive S-corporation income, and positive partnership income, respectively, earned by tax-filing households by percentile of adjusted gross income (AGI). Thus within each series, the values of the one hundred data points sum to 100\%. Panel B decomposes the partnership series of Panel A by plotting positive partnership income earned by tax-filing households by industry, as a share of total positive partnership income earned by tax-filing households. If all partnership industries were shown, the sum of each percentile bin's data points in Panel B would equal the bin's corresponding partnership series data point in Panel A. 
Figure 7: Tax Rate by Entity Type

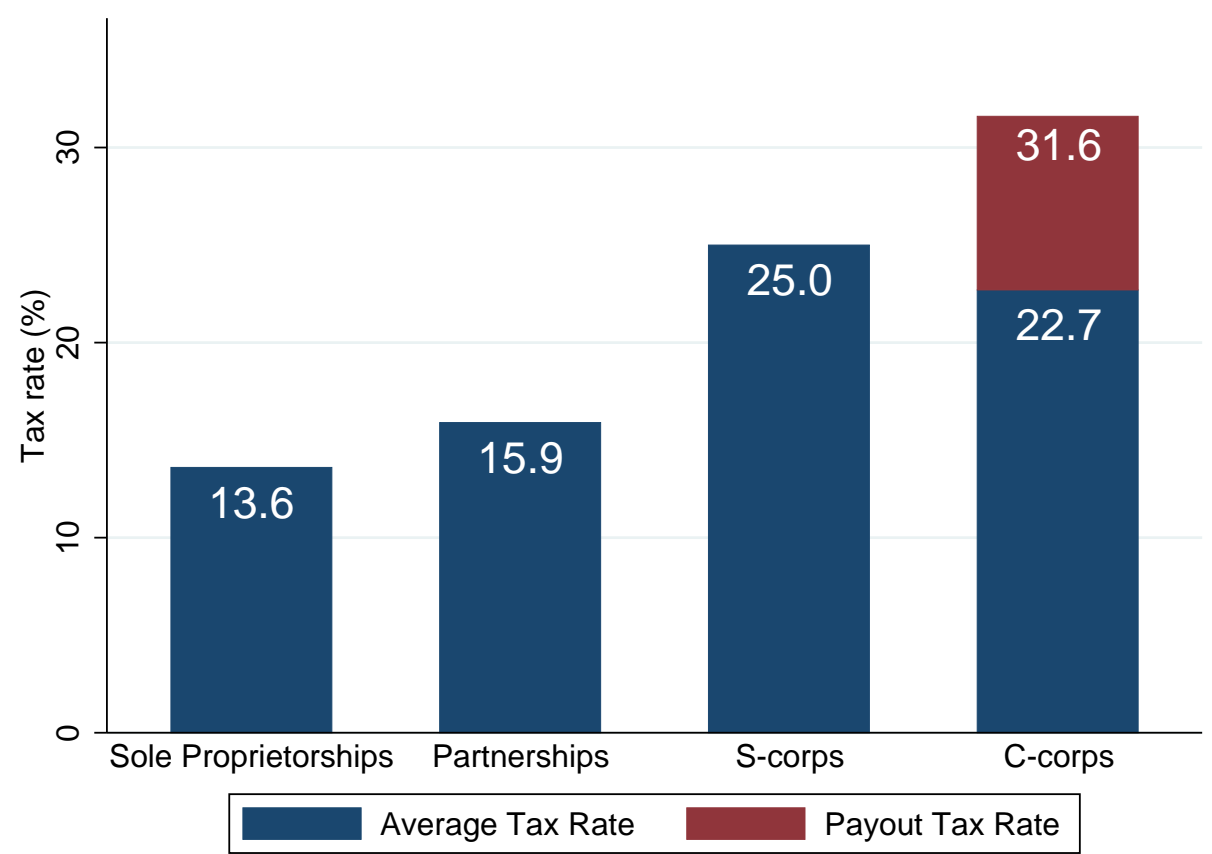

Notes: This figure shows average tax rates by business entity type. Average tax rates are the ratio of a measure of tax liabilities to income. Our measure of tax liability is the difference between the actual tax liability and a hypothetical tax liability that would prevail if income from the sector were set to zero. Sections 3.2, 3.1, 3.3, 3.4 describe these calculations in more detail for Sole Proprietorships, Partnerships, SCorporations, and C-corporations, respectively. The payout rate for C-corporations, including C-corporate partners, is based on existing estimates from the literature and is not independently estimated here as documented in 3.4 . 
Figure 8: Average Tax Rates and Income Composition by Type of Partner

\section{A. Tax Rates on Partnership Income by Type of Partner}

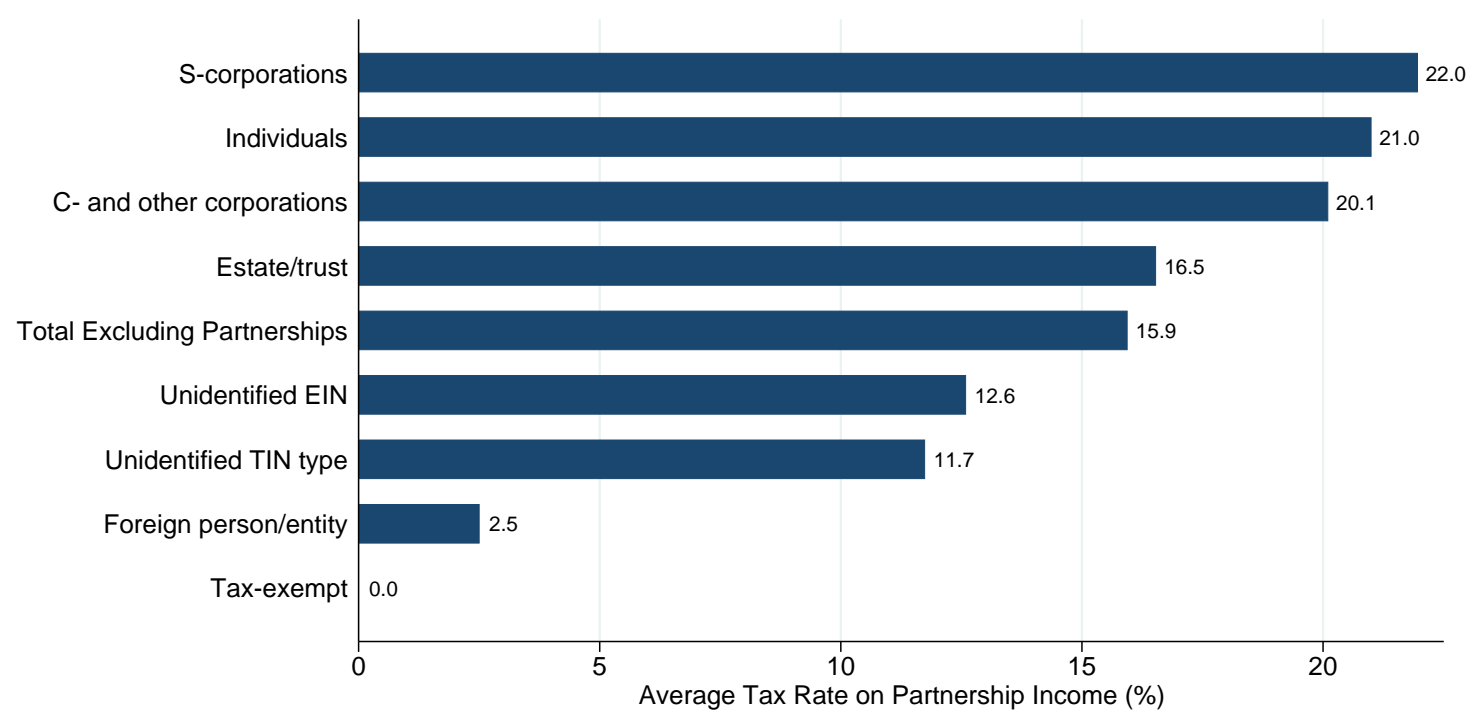

\section{B. Composition of Partnership Income by Type of Partner}

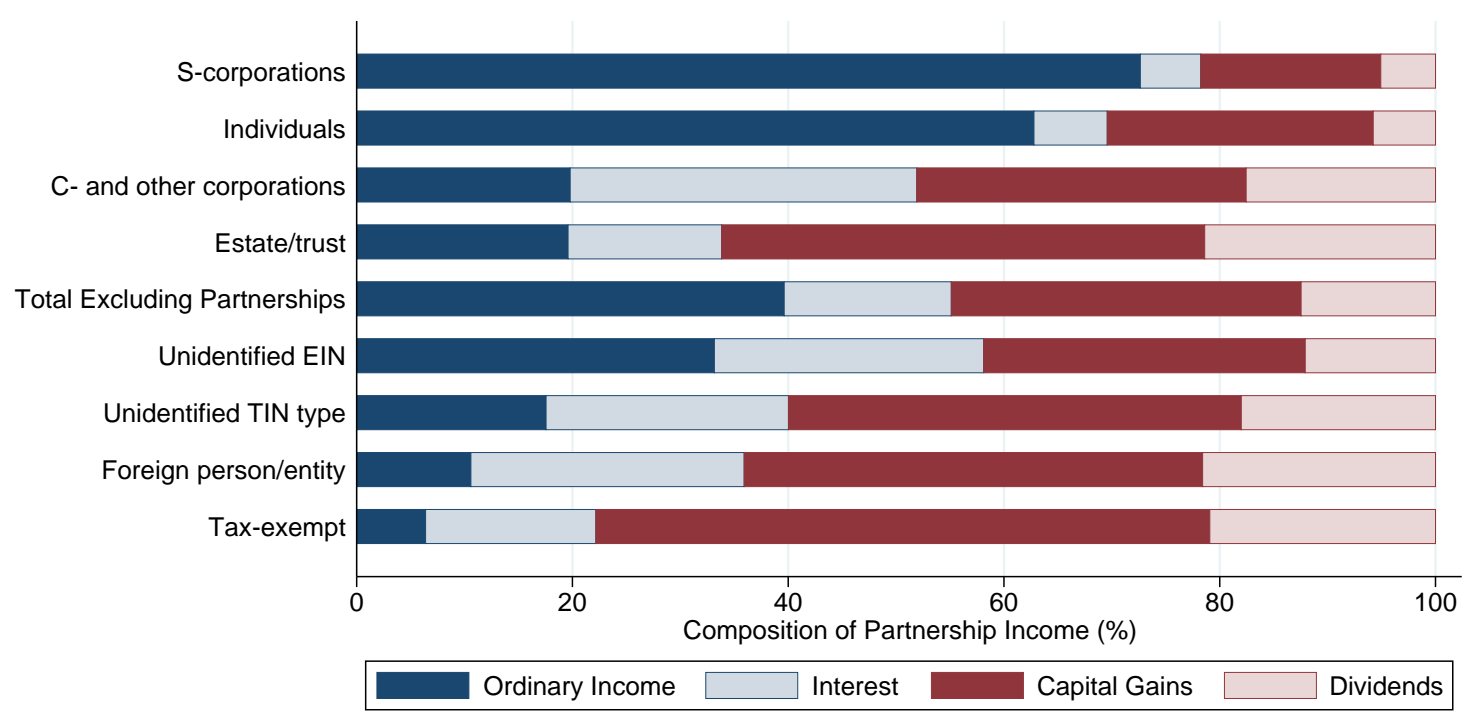

Notes: Panel A plots the average tax rates on partnership income by type of partner. Tax rates are defined as the difference between actual tax liabilities and hypothetical liabilities in the case where all partnership income is zeroed out, divided by partnership income earned. See Section 3.1 for more details on how we calculate this rate for each partner type. Panel B decomposes the partnership income received by each partner type into four income types: ordinary income, interest, short and long-term capital gains, and dividends. See Panels A and B of Figure 3 for K1 counts and total income allocations for these groups. 
Figure 9: Income Distribution and Average Tax Rates by Industry of Partnership

\section{A. Tax Rates on Partnership Income by Industry of Partnership}

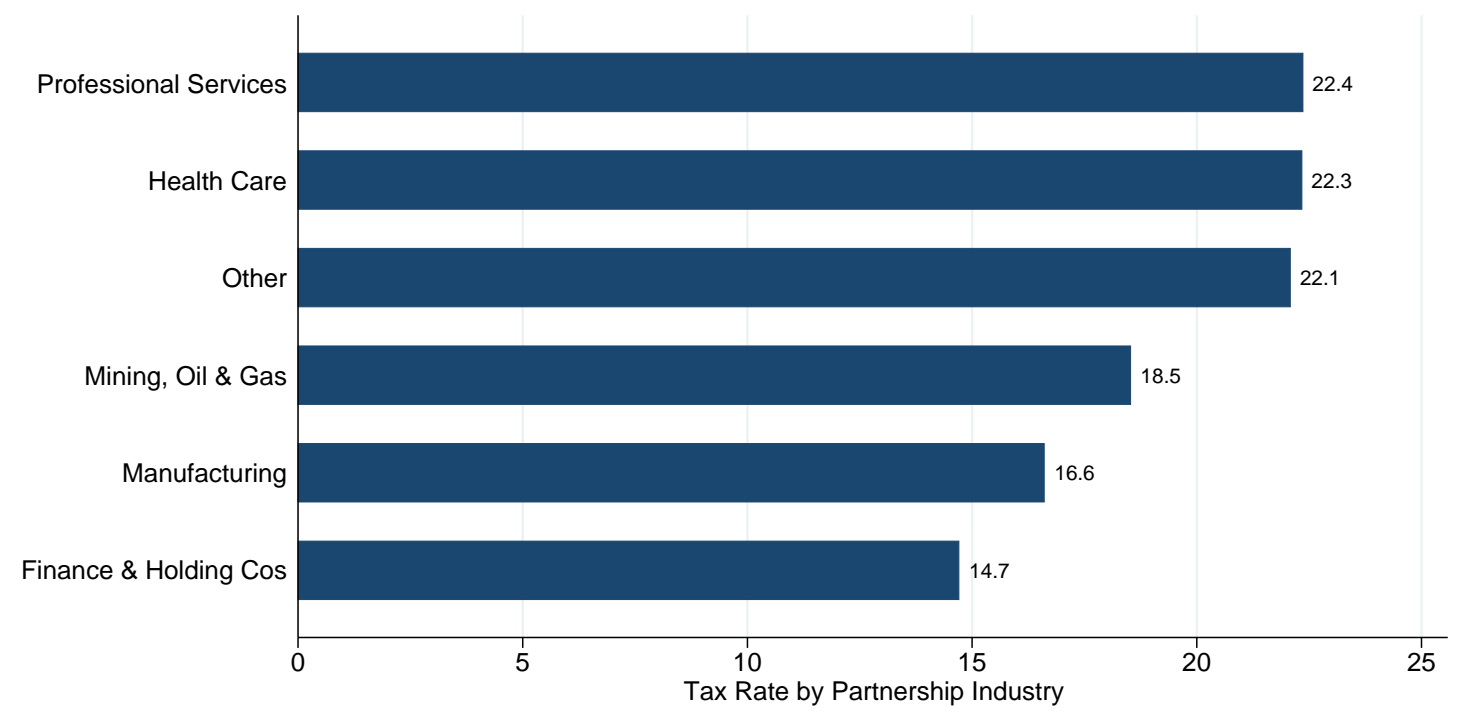

\section{B. Distribution of Partnership Income by Industry of Partnership}

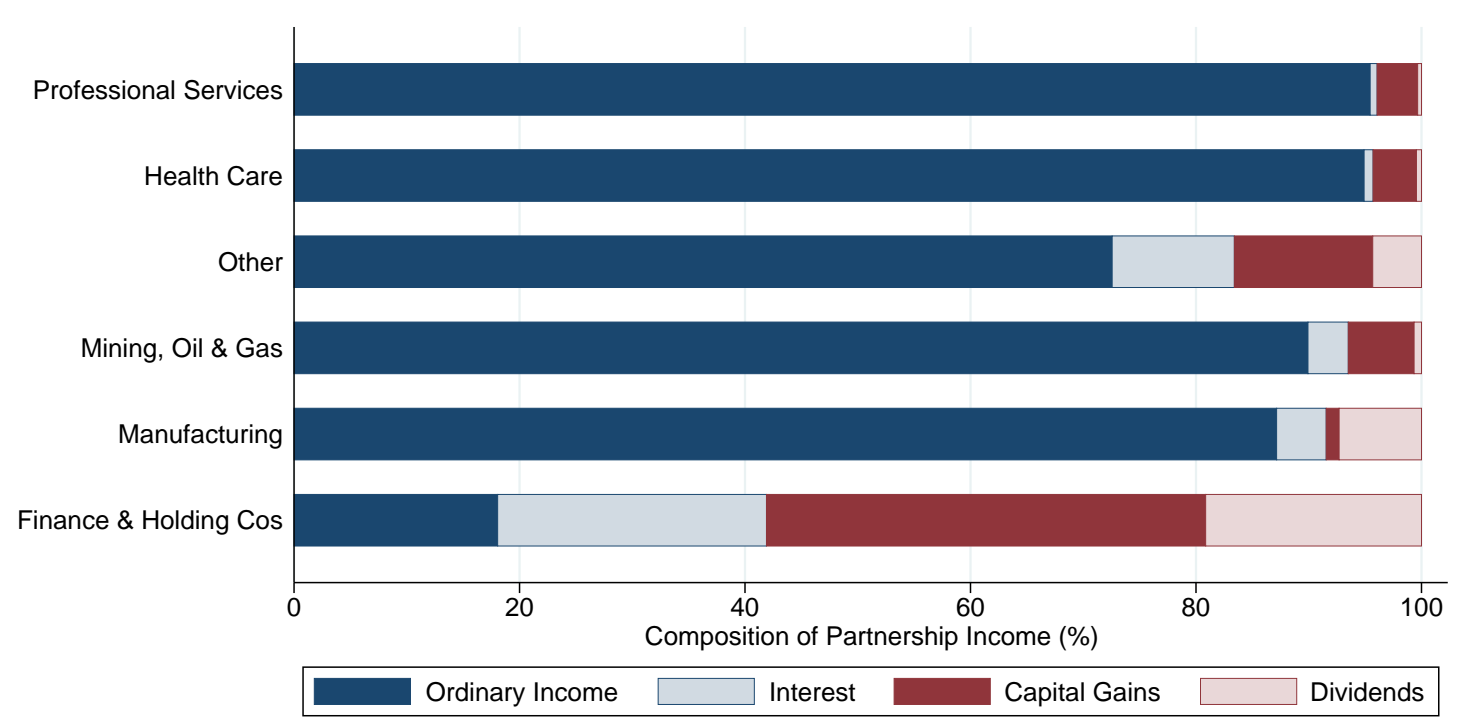

Notes: Panel A plots the average tax rates on partnership income by partnership industry. Tax rates are defined as the difference between actual tax liabilities and hypothetical liabilities in the case where all partnership income is zeroed out, divided by partnership income earned. See section 3.1.2 for more detail on how we calculate this rate for simple partners and appendix A for detail on how we calculate this rate for tiered partnerships. Circular partnerships are excluded from these figures. Panel B decomposes the partnership income received by each partnership industry into four income types: ordinary income, interest, short and long-term capital gains, and dividends. Industry groupings and NAICS codes are as follows: Finance \& Holding Cos (NAICS 52, 55, and 531); Professional Services (NAICS 54); Manufacturing (NAICS 31, 32, and 33); Health Care (NAICS 62); Mining, Oil, \& Gas (NAICS 21). See Figure 4 for total income allocations for these groups. 
Figure 10: Allocation of Gains and Losses in the Partnership Sector by Average Tax Rate

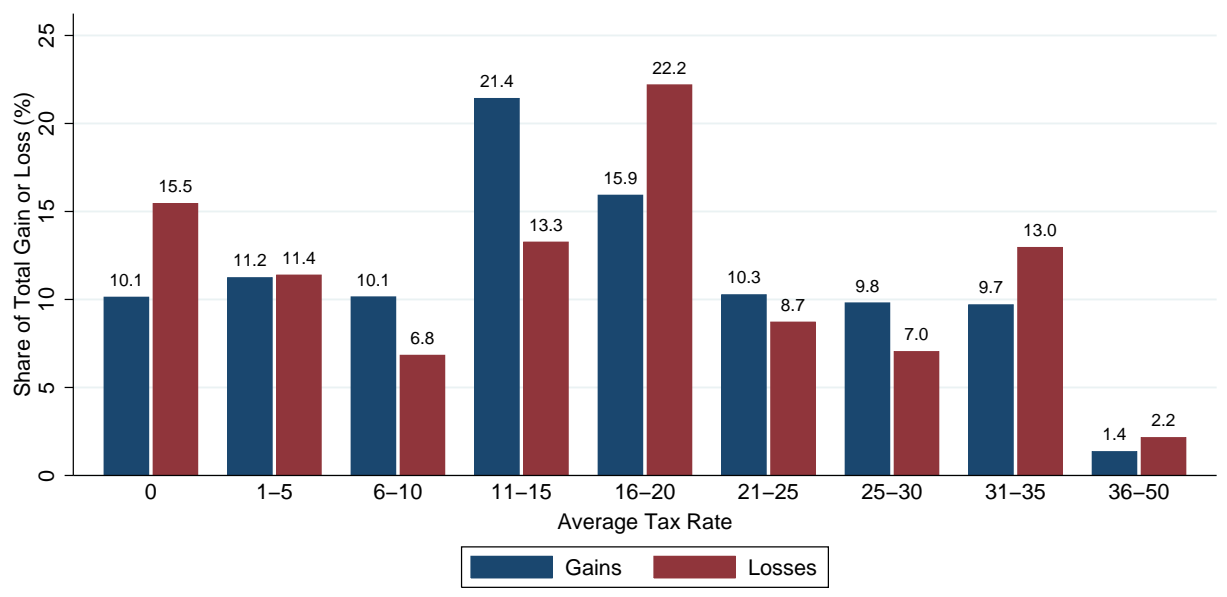

Notes: This figure shows the share of overall gains and losses that are allocated to partners by bins of the average tax rate on that payment. We use our estimated tax rates on every payment from partnerships to partners to assign each payment a tax rate bin. We exclude payments to other partnerships since these payments are ultimately passed through to taxable owners. We classify each payment as a gain if the payment to a partner was positive and as a loss if the payment was negative. We then aggregate total positive payments by tax rate bin and present its share of overall partnership gains. We follow the same procedure for losses. The figure illustrates how gains and losses are allocated across different tax rates. 